\title{
Article \\ Predicting the Mechanical Properties of RCA-Based Concrete Using Supervised Machine Learning Algorithms
}

\author{
Meijun Shang ${ }^{1, *}$, Hejun Li $^{2}$, Ayaz Ahmad ${ }^{3,4, *}$, Waqas Ahmad ${ }^{3}$, Krzysztof Adam Ostrowski ${ }^{4}$ (D) Fahid Aslam ${ }^{5}$, \\ Panuwat Joyklad ${ }^{6}$ and Tomasz M. Majka ${ }^{7}$ (D)
}

1 School of Architetrue and Civil Engineering, Changchun Sci-Tech Unversity, Changchun 130600, China

2 Jilin Northeast Architectural and Municipal Engineering Design Institute Co., Ltd., Changchun 130062, China; lihejun0720@sina.com

3 Department of Civil Engineering, COMSATS University Islamabad, Abbottabad 22060, Pakistan; waqasahmad@cuiatd.edu.pk

4 Faculty of Civil Engineering, Cracow University of Technology, 24 Warszawska Str., 31-155 Cracow, Poland; krzysztof.ostrowski.1@pk.edu.pl

5 Department of Civil Engineering, College of Engineering in Al-Kharj, Prince Sattam Bin Abdulaziz University, Al-Kharj 11942, Saudi Arabia; f.aslam@psau.edu.sa

6 Department of Civil and Environmental Engineering, Faculty of Engineering, Srinakharinwirot University, Nakhonnayok 26120, Thailand; panuwatj@g.swu.ac.th

7 Department of Chemistry and Technology of Polymers, Faculty of Chemical Engineering and Technology, Cracow University of Technology, Warszawska 24, 31-155 Cracow, Poland; tomasz.majka@pk.edu.pl

* Correspondence: shangmeijun0525@sina.com (M.S.); ayazahmad@cuiatd.edu.pk (A.A.)

Citation: Shang, M.; Li, H.; Ahmad A.; Ahmad, W.; Ostrowski, K.A.; Aslam, F.; Joyklad, P.; Majka, T.M. Predicting the Mechanical Properties of RCA-Based Concrete Using Supervised Machine Learning Algorithms. Materials 2022, 15, 647. https://doi.org/10.3390/ma15020647

Academic Editor: Jacek Domski

Received: 25 November 2021

Accepted: 4 January 2022

Published: 15 January 2022

Publisher's Note: MDPI stays neutra with regard to jurisdictional claims in published maps and institutional affiliations.

Copyright: (C) 2022 by the authors. Licensee MDPI, Basel, Switzerland. This article is an open access article distributed under the terms and conditions of the Creative Commons Attribution (CC BY) license (https:// creativecommons.org/licenses/by/ $4.0 /)$.

\begin{abstract}
Environment-friendly concrete is gaining popularity these days because it consumes less energy and causes less damage to the environment. Rapid increases in the population and demand for construction throughout the world lead to a significant deterioration or reduction in natural resources. Meanwhile, construction waste continues to grow at a high rate as older buildings are destroyed and demolished. As a result, the use of recycled materials may contribute to improving the quality of life and preventing environmental damage. Additionally, the application of recycled coarse aggregate (RCA) in concrete is essential for minimizing environmental issues. The compressive strength (CS) and splitting tensile strength (STS) of concrete containing RCA are predicted in this article using decision tree (DT) and AdaBoost machine learning (ML) techniques. A total of 344 data points with nine input variables (water, cement, fine aggregate, natural coarse aggregate, RCA, superplasticizers, water absorption of RCA and maximum size of RCA, density of RCA) were used to run the models. The data was validated using $\mathrm{k}$-fold cross-validation and the coefficient correlation coefficient $\left(\mathrm{R}^{2}\right)$, mean square error (MSE), mean absolute error (MAE), and root mean square error values (RMSE). However, the model's performance was assessed using statistical checks. Additionally, sensitivity analysis was used to determine the impact of each variable on the forecasting of mechanical properties.
\end{abstract}

Keywords: mechanical properties; aggregate; concrete; compressive strength; split tensile strength; fiber

\section{Introduction}

Recently, the use of RA in concrete is gaining favour in the field of research, which gives not only environmentally friendly concrete but also shows satisfactory performance towards the mechanical properties of concrete [1,2]. In the previous decades, the production and utilization trend of sustainable concrete has been significantly increasing due to the high demand of the construction industries [3,4]. The production of concrete is now approximately 1t per human in a one-year period [5]. However, the considerable amount of concrete production fulfills the requirement of construction industries and negatively impacts the environmental conditions [6-9]. The concrete and aggregates production leads to the emission of carbon dioxide, $\mathrm{CO}_{2}$ gas, dust, and other harmful gases, which ultimately results in environmental pollution [10-12]. The demand for waste concrete is 
also increasing because of natural disasters such as earthquakes around the world, leading to serious environmental problems [13-16]. RCA concrete is considered as one of the potential solutions to reduce the utilization rate of the resources produced naturally and uses the waste concrete appearing from natural disasters, also from the demolition of construction $[17,18]$. Although the utilization of RCA in concrete is limited due to low strength, low modulus of elasticity, and high deformation, the desired strength can be achieved by adopting the suitable mix design [19].

The applications of the RCA in concrete can significantly enhance the various properties of concrete by adopting smart techniques of adding other suitable materials to it. Recently, the modern approaches of ML for anticipating results in the field of civil engineering are gaining popularity worldwide. Normally, when it comes to forecasting concrete strength, it normally requires 28 days to achieve its desired strength. The different types of ML approaches may applied to forecast the different properties of concrete without consuming time and money. There are multiple types of ML approaches that are normally applied to forecast the required output such as DT, ANN, and GEP. De-Cheng et al. [20] applied an adaptive boosting approach for the anticipation of CS of concrete in which 1030 data bases were utilized to run the required model and reported $98 \%$ accuracy compared with the actual result. Dong et al. [21] used the ANN model for high-performance concrete, and they also used Monte Carlo simulation to forecast the behavior of high-strength concrete. Muhammad et al. [22] employed GEP to foretell the concrete's strength containing bagasse ash; the predicted accuracy was reported to be more than $80 \%$, indicating better performance. Aliakbar et al. [23] indicated the new formulation for the mechanical properties of RA-based concrete with the help of GEP, and they also analyzed that the prediction level was close to the actual results. They investigated the CS, flexural strength, and STS from the retrieved data. Taihao et al. [24] represented their work on the application of ensemble ML techniques for the forecast and optimization of young's modulus, having RA concrete, the RF, and SVM employed on data for prediction, which shows the accurate prediction of the outcome.

The focus of this research is based on the prediction of two properties (STS and CS) of concrete containing RCA via supervised ML algorithms [25]. The performance of both models was analyzed and compared to evaluate the better performer for the prediction of results. The accuracy level between the real and anticipated output was observed from the coefficient correlation $\left(R^{2}\right)$ value, and a higher value gives the impressive performance of the employed model. The AdaBoost technique was employed for optimization via producing 20 sub-models to obtain a higher $\mathrm{R}^{2}$ value [26]. The application of these ML algorithms is to compare the predictive evaluation of each approach. The significance of this study is to determine the effect of the input factors used to anticipate the mechanical characteristics of concrete and the predictive accuracy of both methodologies. The research is innovative in that it uses the type of ML techniques and individual (DT) and ensemble (AdaBoost) ML algorithms to forecast the two outcomes (CS, STS) of recycled coarse aggregate concrete (RCA). The statistical application of checks was applied to analyze the nature of both techniques. In addition, the sensitivity analysis was also incorporated, which indicates the performance level of each input parameter for the anticipation of both STS and CS.

\section{Methodology and Description of Data}

The model's performance is based on the input variables and the number of databases used to run the model. The parameters used in this study for running the models to predict the CS and STS of RCA-based concrete were taken from the published literature and are available in Appendix A [27]. The anaconda navigator software was used in this research and incorporated Python coding to run the models for forecasting the results. The excel file with relevant input and output data was uploaded to the software, which runs the model as per the data available in the file. The outcome from the model was then imported for graphical representation. The running of the models comprised nine input parameters 
(cement, water, fine aggregate, natural CA, RCA, superplasticizers, maximum size of RCA, density of RCA, water absorption of RCA) and two output parameters (CS and STS). The relative frequency distribution of the nine variables can be seen in Figure 1. The relevant references regarding the application of various ML approaches are listed in Table 1. The descriptive statistical analysis for input parameters is illustrated in Table 2, indicating the various mathematical description and ranges of input parameters. In addition, the methodology of the research approach is presented via flowchart, as depicted in Figure 2, which represents the information of the stepwise adopted procedure of the study. The first phase indicates the information of the data obtained, and then the analysis took place using machine learning algorithms, while result explanation, comparison, and evaluation are presented in the next step of the flowchart.

Table 1. Various predicted properties with the application of ML approaches.

\begin{tabular}{|c|c|c|c|c|c|c|c|}
\hline Sr. No & $\begin{array}{l}\text { Algorithm } \\
\text { Used }\end{array}$ & Notation & Data Points & $\begin{array}{l}\text { Prediction } \\
\text { Properties }\end{array}$ & Year & $\begin{array}{l}\text { Material } \\
\text { Used }\end{array}$ & References \\
\hline 1. & $\begin{array}{l}\text { Support vector } \\
\text { machine }\end{array}$ & SVM & 144 & CS & 2021 & Fly ash (FA) & [28] \\
\hline 2. & $\begin{array}{c}\text { Gene } \\
\text { expression } \\
\text { programming }\end{array}$ & GEP & 303 & $\begin{array}{l}\text { Column's } \\
\text { bearing } \\
\text { capacity }\end{array}$ & 2019 & - & [29] \\
\hline 3. & $\begin{array}{l}\text { Data } \\
\text { Envelopment } \\
\text { Analysis }\end{array}$ & DEA & 114 & $\begin{array}{l}\text { Fresh and } \\
\text { harden } \\
\text { properties of } \\
\text { concrete }\end{array}$ & 2021 & FA & [30] \\
\hline 4. & $\begin{array}{c}\text { Gene } \\
\text { expression } \\
\text { programming, } \\
\text { Artificial } \\
\text { neural } \\
\text { network, } \\
\text { Decision tree }\end{array}$ & $\begin{array}{c}\text { GEP, ANN, } \\
\text { DT }\end{array}$ & 642 & $\begin{array}{l}\text { Surface } \\
\text { Chloride } \\
\text { Concentra- } \\
\text { tion }\end{array}$ & 2021 & FA & [31] \\
\hline 5. & $\begin{array}{l}\text { Support vector } \\
\text { machine }\end{array}$ & SVM & - & CS & 2020 & FA & [32] \\
\hline 6. & $\begin{array}{l}\text { Support vector } \\
\text { machine }\end{array}$ & SVM & 115 & $\begin{array}{l}\text { Fresh } \\
\text { properties of } \\
\text { concrete CS }\end{array}$ & 2020 & FA & [33] \\
\hline 7. & $\begin{array}{c}\text { Gene } \\
\text { Expression } \\
\text { Programming }\end{array}$ & GEP & 351 & CS & 2020 & $\begin{array}{c}\text { Ground } \\
\text { Granulated } \\
\text { Blast Furnace } \\
\text { Slag }\end{array}$ & [34] \\
\hline 8. & $\begin{array}{c}\text { Gene } \\
\text { Expression } \\
\text { Programming }\end{array}$ & GEP & 54 & CS & 2019 & $\begin{array}{l}\text { NZ (Natural } \\
\text { Zeolite) }\end{array}$ & [34] \\
\hline 9. & $\begin{array}{c}\text { Gene } \\
\text { expression } \\
\text { programming }\end{array}$ & GEP & 357 & CS & 2020 & - & [35] \\
\hline 10. & $\begin{array}{l}\text { Random forest } \\
\text { and gene } \\
\text { expression } \\
\text { programming }\end{array}$ & RF and GEP & 357 & CS & 2020 & - & [36] \\
\hline 11. & $\begin{array}{c}\text { Artificial } \\
\text { neuron } \\
\text { network }\end{array}$ & ANN & 205 & CS & 2019 & $\begin{array}{c}\text { Fly ash } \\
\text { GGBFS } \\
\text { Rice husk ash }\end{array}$ & [37] \\
\hline
\end{tabular}


Table 1. Cont.

\begin{tabular}{|c|c|c|c|c|c|c|c|}
\hline Sr. No & $\begin{array}{l}\text { Algorithm } \\
\text { Used }\end{array}$ & Notation & Data Points & $\begin{array}{l}\text { Prediction } \\
\text { Properties }\end{array}$ & Year & $\begin{array}{l}\text { Material } \\
\text { Used }\end{array}$ & References \\
\hline 12. & $\begin{array}{c}\text { Intelligent } \\
\text { rule-based } \\
\text { enhanced } \\
\text { multiclass } \\
\text { support vector } \\
\text { machine and } \\
\text { fuzzy rules }\end{array}$ & $\begin{array}{l}\text { IREMSVM- } \\
\text { FR with } \\
\text { RSM }\end{array}$ & 114 & CS & 2019 & Fly ash & [38] \\
\hline 13. & Random forest & RF & 131 & CS & 2019 & $\begin{array}{c}\text { Fly ash } \\
\text { GGBFS } \\
\text { FA }\end{array}$ & [39] \\
\hline 14. & $\begin{array}{l}\text { Multivariate } \\
\text { adaptive } \\
\text { regression } \\
\text { spline }\end{array}$ & $\begin{array}{c}\text { M5 } \\
\text { MARS }\end{array}$ & 114 & $\begin{array}{c}\text { CS } \\
\text { Slump test } \\
\text { L-box test } \\
\text { V-funnel test }\end{array}$ & 2018 & FA & [40] \\
\hline 15. & $\begin{array}{l}\text { Random } \\
\text { Kitchen Sink } \\
\text { Algorithm }\end{array}$ & RKSA & 40 & $\begin{array}{c}\text { V-funnel test } \\
\text { J-ring test } \\
\text { Slump test } \\
\text { CS }\end{array}$ & 2018 & FA & [41] \\
\hline 16. & $\begin{array}{l}\text { Adaptive } \\
\text { neuro fuzzy } \\
\text { inference } \\
\text { system }\end{array}$ & ANFIS & 55 & CS & 2018 & - & [42] \\
\hline 17. & $\begin{array}{l}\text { Artificial } \\
\text { neuron } \\
\text { network }\end{array}$ & ANN & 114 & CS & 2017 & FA & [43] \\
\hline 18. & $\begin{array}{l}\text { Artificial } \\
\text { neuron } \\
\text { network }\end{array}$ & ANN & 69 & CS & 2017 & FA & [44] \\
\hline 19 & $\begin{array}{l}\text { Individual and } \\
\text { ensemble } \\
\text { algorithm }\end{array}$ & $\begin{array}{l}\text { GEP, DT, } \\
\text { Bagging }\end{array}$ & 270 & CS & 2021 & FA & [45] \\
\hline 20. & $\begin{array}{l}\text { Individual } \\
\text { with ensemble } \\
\text { modeling }\end{array}$ & $\begin{array}{l}\text { ANN, } \\
\text { bagging, } \\
\text { boosting }\end{array}$ & 1030 & CS & 2021 & FA & [46] \\
\hline 21. & Multivariate & MV & 21 & CS & 2020 & $\begin{array}{l}\text { Crumb } \\
\text { rubber with } \\
\text { SF }\end{array}$ & [47] \\
\hline 22. & $\begin{array}{c}\text { Gene } \\
\text { expression } \\
\text { programming }\end{array}$ & GEP & 277 & $\begin{array}{c}\text { Axial } \\
\text { capacity }\end{array}$ & 2020 & 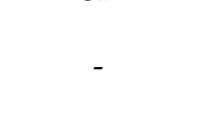 & [48] \\
\hline 23. & $\begin{array}{l}\text { Adaptive } \\
\text { neuro fuzzy } \\
\text { inference } \\
\text { system }\end{array}$ & $\begin{array}{l}\text { ANFIS with } \\
\text { ANN }\end{array}$ & 7 & CS & 2020 & $\begin{array}{l}\text { Palm oil fuel } \\
\text { ash }\end{array}$ & [49] \\
\hline 24. & $\begin{array}{l}\text { Response } \\
\text { Surface } \\
\text { Method, Gene } \\
\text { expression } \\
\text { programming }\end{array}$ & RSM, GEP & 108 & CS & 2020 & Steel Fibers & [50] \\
\hline 25. & $\begin{array}{c}\text { Artificial } \\
\text { neural network }\end{array}$ & ANN & 60 & CS & 2021 & $\begin{array}{l}\text { Ceramic } \\
\text { waste } \\
\text { powder }\end{array}$ & [51] \\
\hline
\end{tabular}


Table 1. Cont.

\begin{tabular}{|c|c|c|c|c|c|c|c|}
\hline Sr. No & $\begin{array}{l}\text { Algorithm } \\
\text { Used }\end{array}$ & Notation & Data Points & $\begin{array}{l}\text { Prediction } \\
\text { Properties }\end{array}$ & Year & $\begin{array}{c}\text { Material } \\
\text { Used }\end{array}$ & References \\
\hline 27. & $\begin{array}{c}\text { Decision tree, } \\
\text { Artificial } \\
\text { neural } \\
\text { network, } \\
\text { Bagging, } \\
\text { Gradient } \\
\text { boosting }\end{array}$ & $\begin{array}{l}\text { DT, ANN, } \\
\text { BR, GB }\end{array}$ & 207 & CS & 2021 & FA & [52] \\
\hline 28. & $\begin{array}{c}\text { Gene } \\
\text { expression } \\
\text { programming, } \\
\text { Artificial } \\
\text { neural } \\
\text { network, } \\
\text { Decision tree }\end{array}$ & $\begin{array}{c}\text { GEP, ANN, } \\
\text { DT }\end{array}$ & 98 & CS & 2021 & FA & [53] \\
\hline 29. & $\begin{array}{c}\text { Individual and } \\
\text { Ensemble } \\
\text { techniques }\end{array}$ & BR, GEP, DT & 1030 & CS & 2021 & FA & [54] \\
\hline
\end{tabular}

Table 2. Details of the descriptive analysis.

\begin{tabular}{|c|c|c|c|c|c|c|c|c|c|}
\hline Statistics & Water & Cement & FA & NCA & RCA & SP & RCA Size & $\begin{array}{c}\text { RCA } \\
\text { Density }\end{array}$ & Absorption \\
\hline Mean & 184.62 & 386.86 & 681.89 & 398.07 & 650.74 & 1.32 & 19.76 & 2231.06 & 4.80 \\
\hline $\begin{array}{l}\text { Standard } \\
\text { Error }\end{array}$ & 1.39 & 4.43 & 11.07 & 19.99 & 20.37 & 0.11 & 0.22 & 31.32 & 0.12 \\
\hline Median & 180.00 & 380.00 & 698.00 & 471.00 & 552.00 & 0.00 & 20.00 & 2362.50 & 4.90 \\
\hline Mode & 220.00 & 380.00 & 693.00 & 0.00 & 138.00 & 0.00 & 20.00 & 2320.00 & 5.30 \\
\hline $\begin{array}{l}\text { Standard } \\
\text { Deviation }\end{array}$ & 25.84 & 82.16 & 205.28 & 370.71 & 377.73 & 2.05 & 4.02 & 580.95 & 2.26 \\
\hline $\begin{array}{l}\text { Sample } \\
\text { Variance }\end{array}$ & 667.47 & 6750.28 & $42,141.11$ & $137,424.94$ & $142,682.56$ & 4.21 & 16.16 & $337,504.80$ & 5.12 \\
\hline Minimum & 117.6 & 158 & 0 & 0.00 & 52 & 0. & 10 & 0 & 0 \\
\hline Maximum & 271. & 600 & 1010 & 1448 & 1778 & 7.8 & 32 & 2661 & 10.9 \\
\hline Sum & $63,510.69$ & $133,081.00$ & 234,568 & 136,937 & 223,853 & 455.5 & 6796 & 767,484 & 1652.8 \\
\hline Count & 344.00 & 344.00 & 344 & 344 & 344 & 344 & 344 & 344 & 344 \\
\hline
\end{tabular}



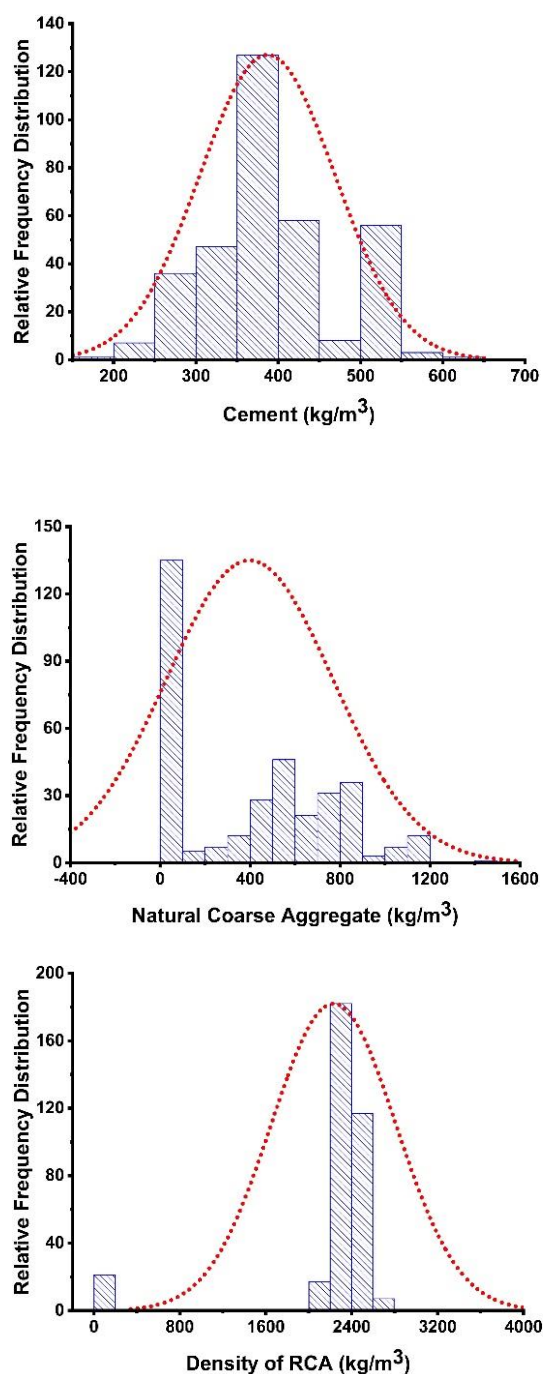

Figure 1. Histograms of the input parameters showing the relative frequency scattering
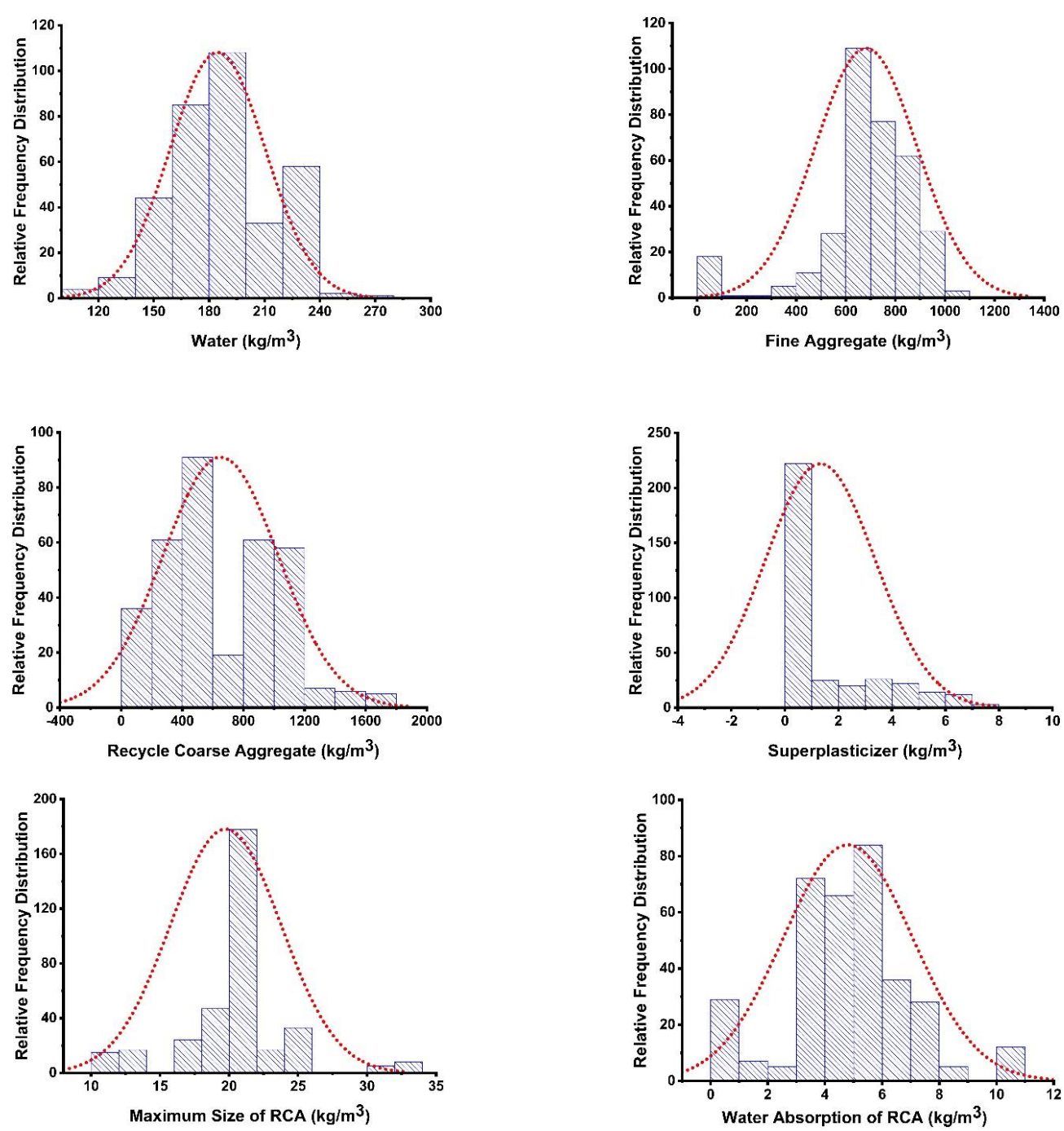


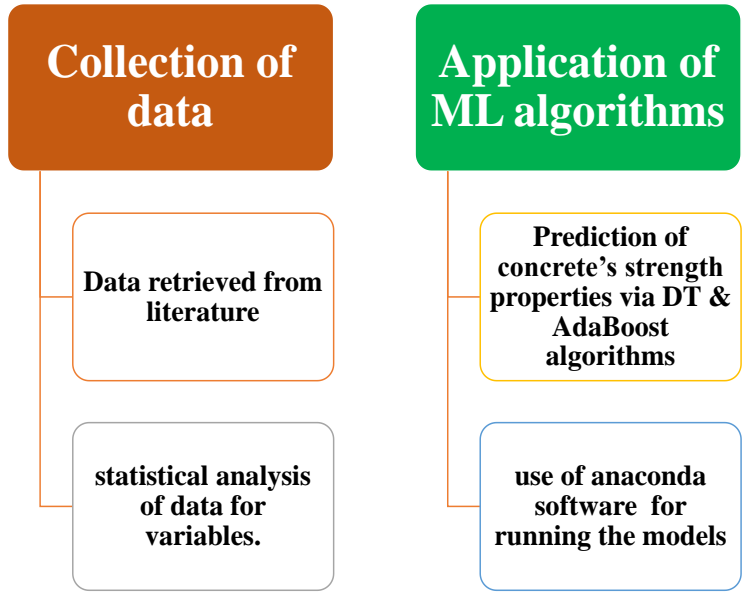

Figure 2. Flow chart of the research program.

\section{Supervised Machine Learning Algorithms}

\subsection{Decision Tree Algorithm}

The DT algorithm is a subset of the supervised machine learning (ML) technique known as individual supervised machine learning (ISML). It is applicable to classification and regression problems. This approach aims to generate a model that can forecast the targeted variable, for which it uses the representation of a tree to solve the problem. In machine learning, the classification process has two steps, the learning and forecasting steps. The learning step belongs to the development of the model based on the given data set, while, in the prediction step, said model is then used to foretell the response of the data. A decision tree is a well-known and effective classification technique that is simple to comprehend and apply. Sub-node creation improves the homogeneity of specific sub-nodes. There are several important terminologies associated with the decision tree. These include root nodes, which indicate the overall population of the sets; splitting, which refers to the process of dividing the nodes; decision nodes, which refers to the process of splitting sub-nodes into further sub-nodes; leaf nodes, which are the type of nodes that do not split; and pruning, which refers to the process of removing sub-nodes.

\subsection{AdaBoost Algorithm}

The AdaBoost regressor is a supervised ML technique that uses an ensemble approach. It is also known as adaptive boosting because the weights are re-assigned to each instance, with greater weights going to instances that were mistakenly identified. Boosting techniques are commonly used in supervised learning to reduce bias and variation. These ensemble algorithms are used to improve the performance of the weak learner. During the training phase for the input data, it uses an endless number of decision trees. The recorded data that are incorrectly categorized throughout the initial model are given a high priority while developing the initial decision tree/model. These are the only data entries that are utilized as the input for a different model. The preceding technique will be repeated until the desired number of basic learners has been reached. When it comes to binary classification problems, the AdaBoost regressor outperforms the competition in terms of improving decision tree performance. It is also used to boost the efficiency of other machine learning methods. When used with a slow student, it is quite beneficial. The use 
of these ensemble methods is most common in civil engineering, especially when it comes to predicting the mechanical properties of different types of concrete.

\section{Result and Their Analyses}

\subsection{Statistical Analysis}

The result obtained from the statistical analyses indicated that the relationship between the actual and predicted outcomes (CS and STS) from the individual and ensemble ML algorithms, along with the distribution of errors, is explained as follows.

\subsubsection{Compressive Strength Result Using Decision Tree}

The relationship between the actual and predicted result of compressive strength for the decision tree algorithm can be seen in Figure 3 a, along with the distribution of the errors shown in Figure $3 \mathrm{~b}$. The errors distribution for DT gives the maximum, minimum, and average values equal to $8.82 \mathrm{MPa}, 0.58 \mathrm{MPa}$, and $3.58 \mathrm{MPa}$, respectively. However, $11.59 \%$ of the error data lie between 0 and $1 \mathrm{MPa}$, and $50.72 \%$ of the data lie between $2 \mathrm{MPa}$ and $6 \mathrm{MPa}$. In addition, only $8.69 \%$ of the data lie above $7 \mathrm{MPa}$.

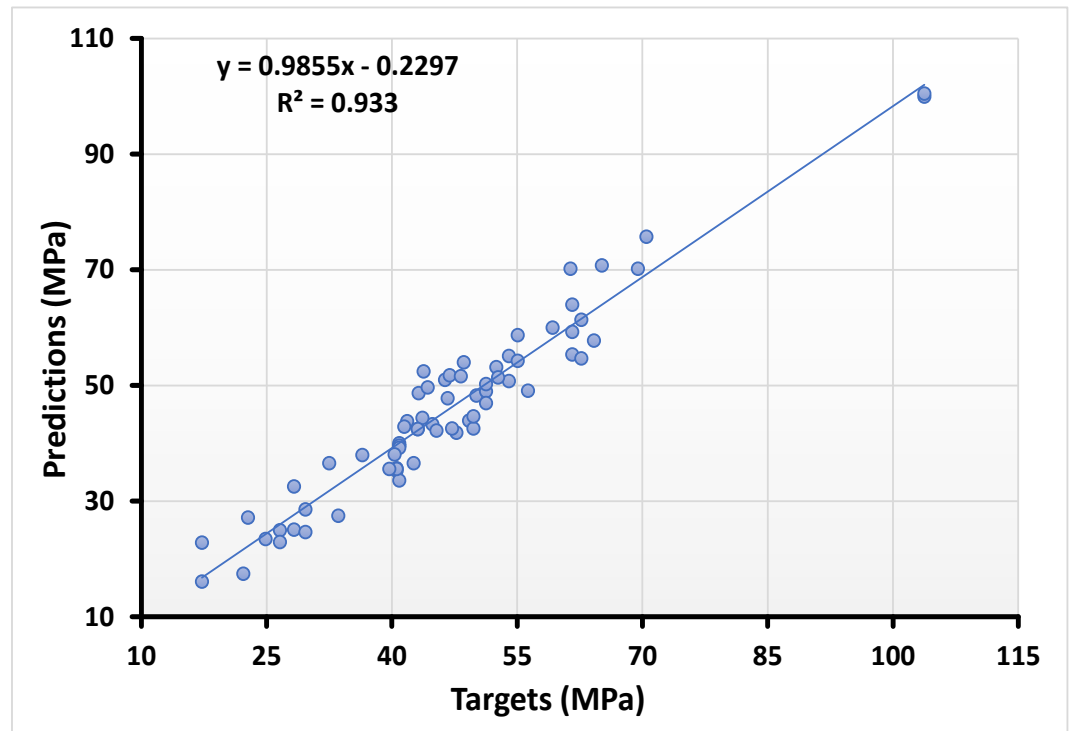

(a)

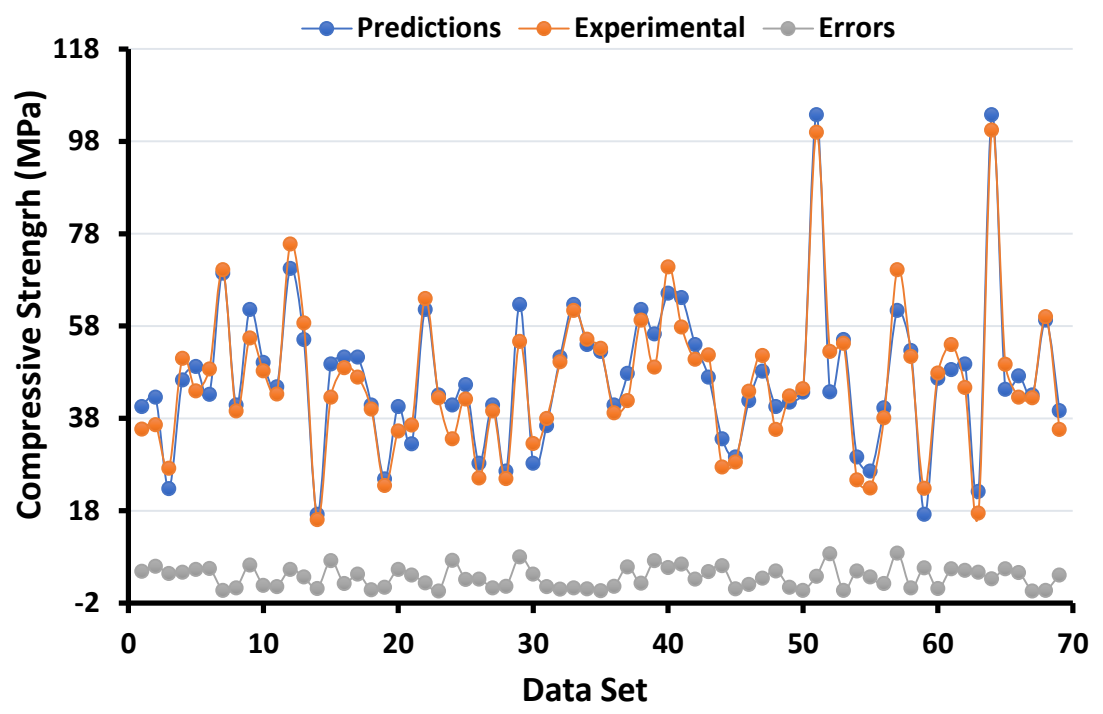

(b)

Figure 3. Numerical analyses representing the relationship between the predicted variables and targeted variables (a) along with their error distribution (b) for compressive strength using DT. 


\subsubsection{Splitting Tensile Strength Result Using Decision Tree}

The relation of the actual and predicted outcome of splitting tensile strength using the DT approach in depicted in Figure 4a along with its error distribution depicted in Figure 4b. The error distribution indicates the higher, lower, and average values equal to $2.47 \mathrm{MPa}, 0$, and $0.31 \mathrm{MPa}$, respectively. In contrast, $42.02 \%$ of the error data lie between 0 and $0.1 \mathrm{MPa}$, while $34.78 \%$ of the data lie between $0.1 \mathrm{MPa}$ and $0.5 \mathrm{MPa}$. However, only $8.69 \%$ of the error data were reported as above $1 \mathrm{MPa}$.

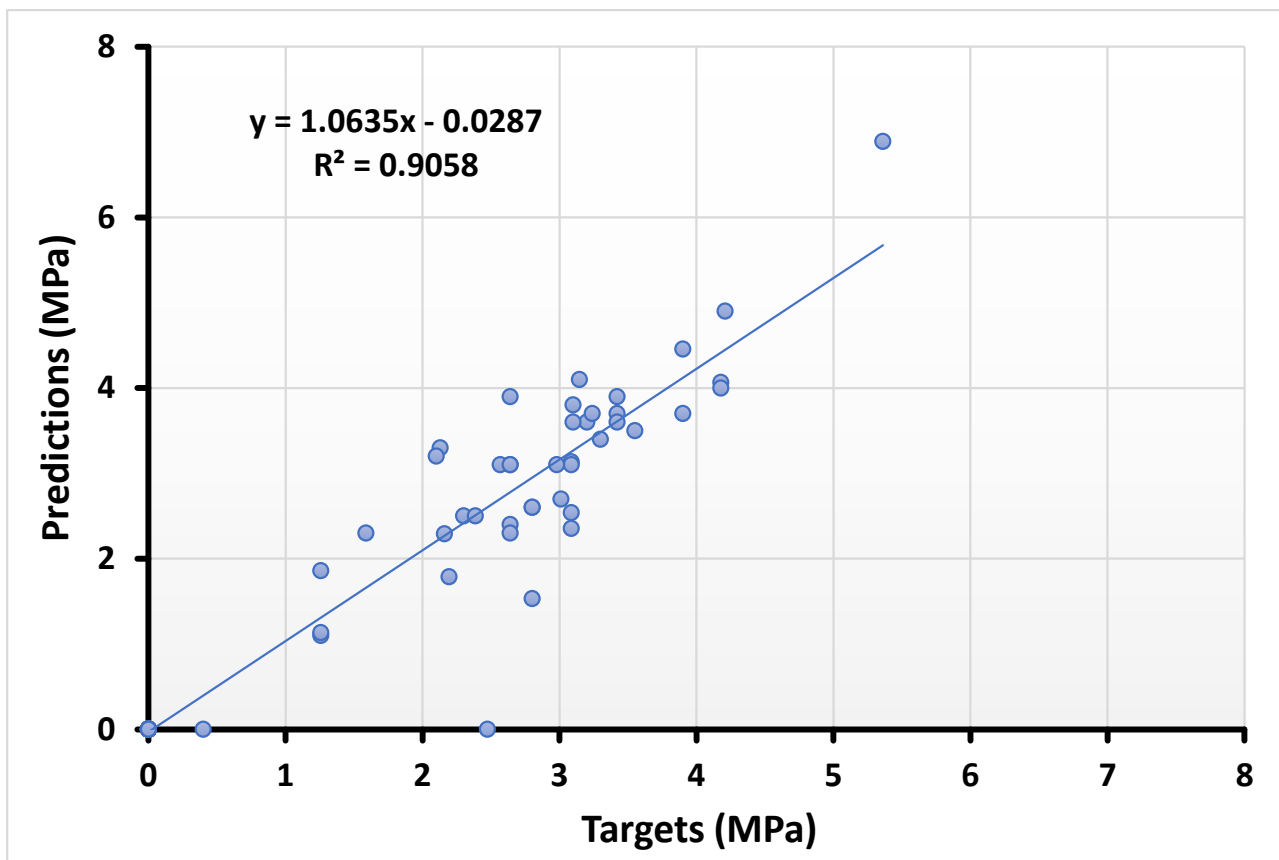

(a)

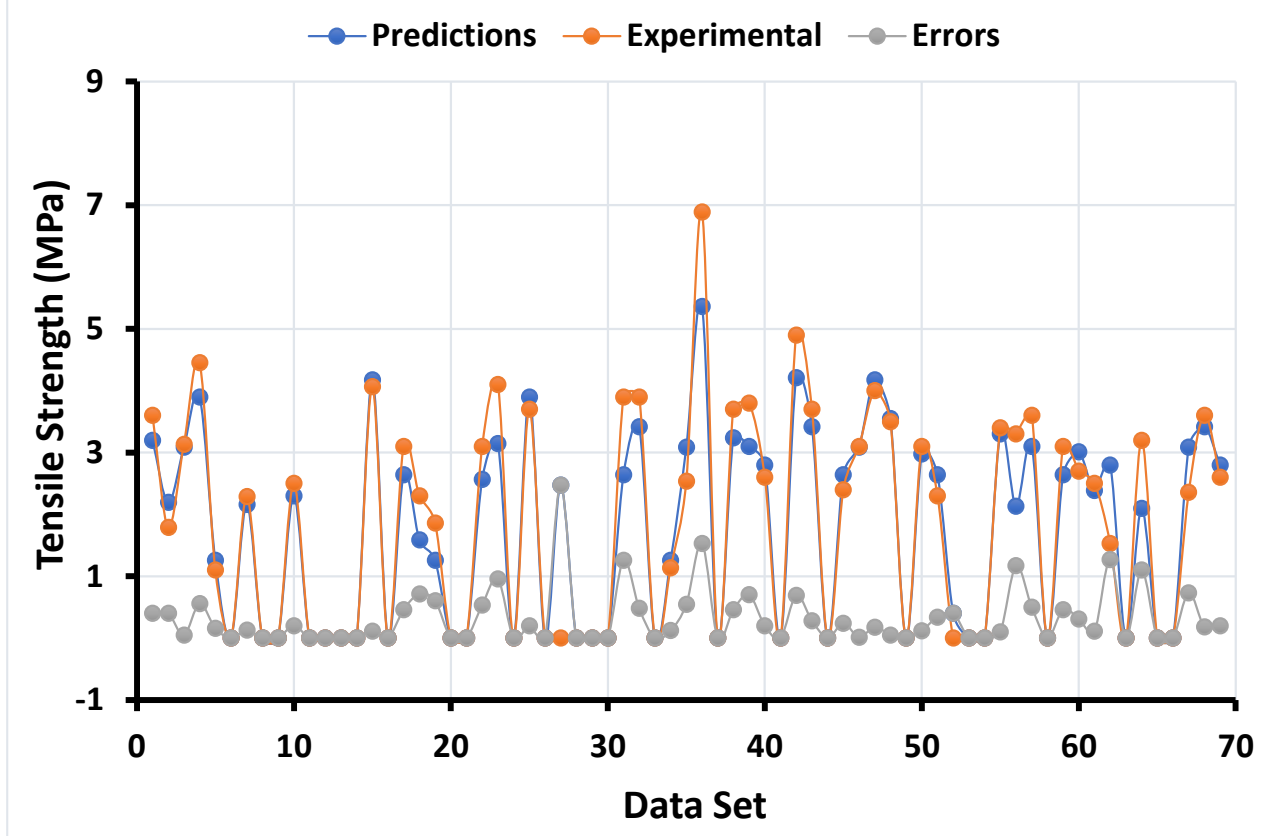

(b)

Figure 4. Numerical analyses representing the relationship between the predicted variables and targeted variables (a) along with their error distribution (b) for splitting tensile strength using DT. 


\subsubsection{Compressive Strength Result with AdaBoost Regressor}

AdaBoost regressor gives strong relation between the real and anticipated output, as shown in Figure 5a, while the distribution of the error's value can be seen in Figure 5b. It shows the maximum, lower, and average values of the error data equal to $13 \mathrm{MPa}, 0.06 \mathrm{MPa}$, and $2.33 \mathrm{MPa}$, respectively. Additionally, $26.08 \%$ of the error data were reported between 0 and $1 \mathrm{MPa}$, while $34.78 \%$ of the data lie between $2 \mathrm{MPa}$ and $6 \mathrm{MPa}$. However, $4.34 \%$ of the error data were reported to be above $7 \mathrm{MPa}$.

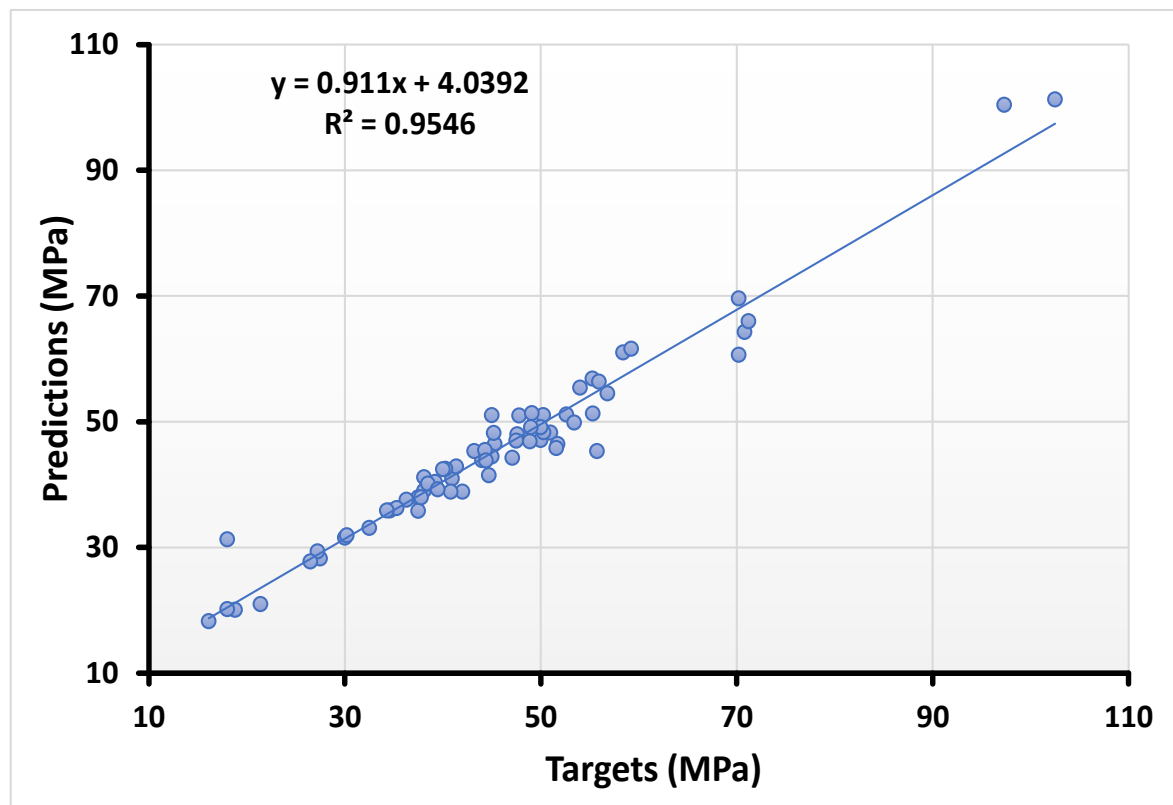

(a)

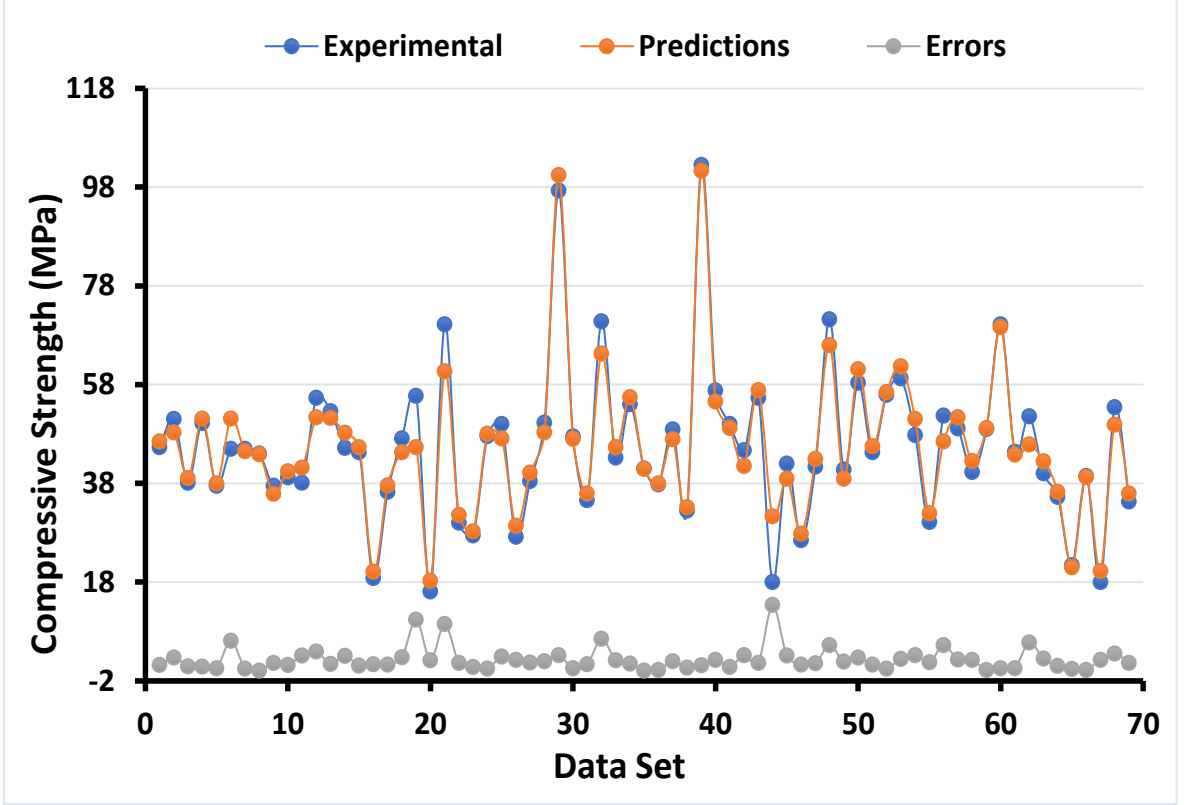

(b)

Figure 5. Numerical analyses representing the relationship between the predicted variables and targeted variables (a) along with their error distribution (b) for compressive strength using the AdaBoost regressor. 


\subsubsection{Splitting Tensile Strength with AdaBoost Regressor}

The statistical result of splitting tensile strength using the AdaBoost regressor also shows strong relations with less variance among the experimental results obtained from the model, as depicted in Figure 6a. The distribution of the errors obtained from the application of the AdaBoost regressor can be seen in Figure $6 \mathrm{~b}$. The error distribution shows the maximum, minimum, and average values equal to $1.46 \mathrm{MPa}, 0$, and $0.30 \mathrm{MPa}$, respectively. However, $36.26 \%$ of the error data lie between 0 and $0.1 \mathrm{MPa}$, while $34.78 \%$ of the data lie between $0.1 \mathrm{MPa}$ and $0.5 \mathrm{MPa}$. In addition, only $4.34 \%$ of the errors data lie above $1 \mathrm{MPa}$.

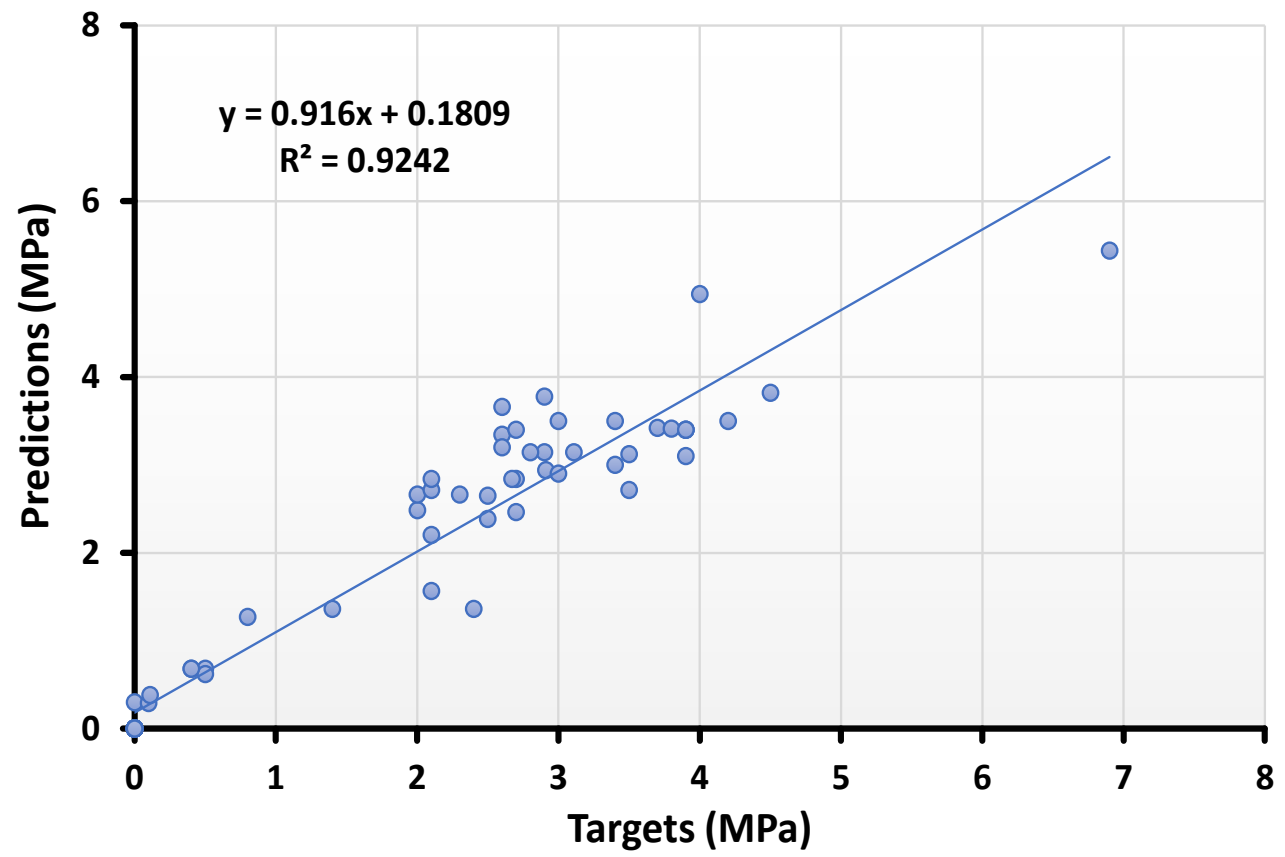

(a)

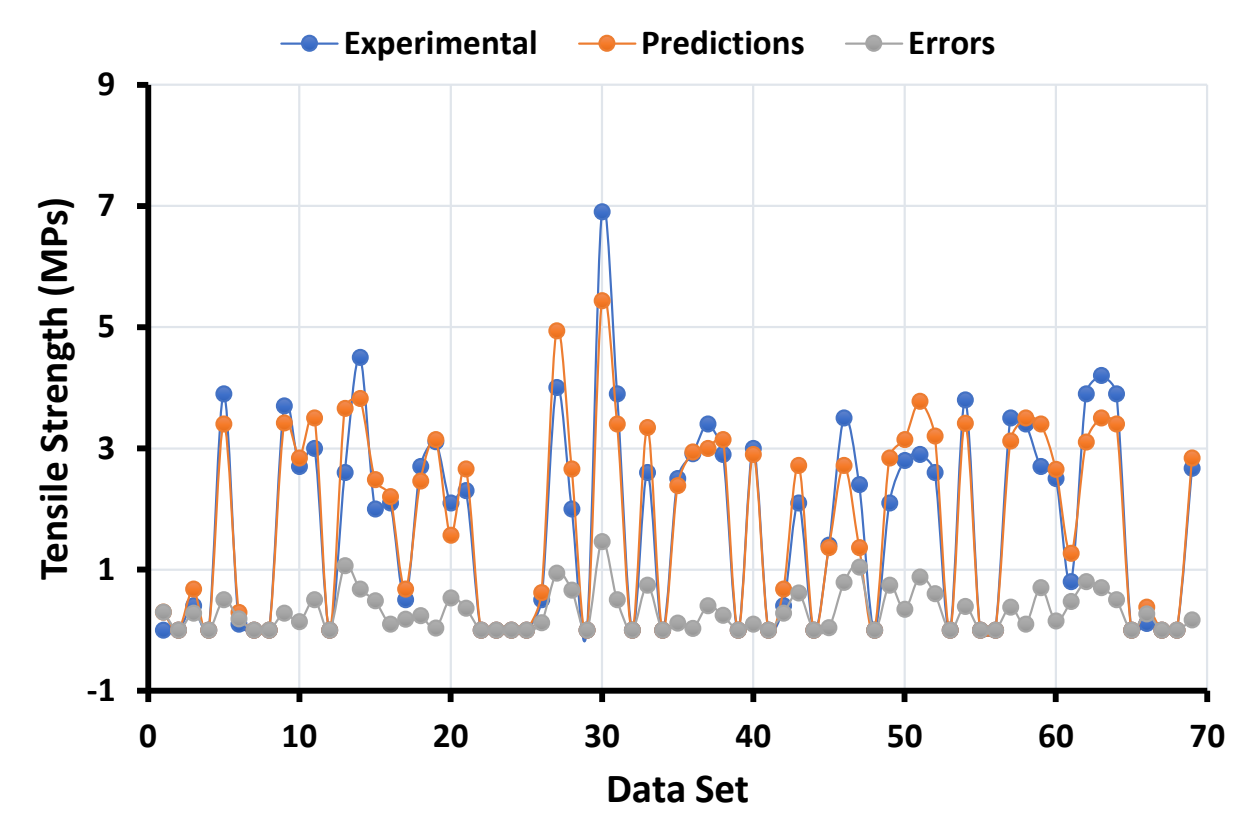

(b)

Figure 6. Numerical analyses representing the relationship between the predicted variables and targeted variables (a) along with their error distribution (b) for splitting tensile strength using the AdaBoost regressor. 


\subsection{K-Fold Cross-Validation and Statistical Checks}

This process is normally adopted to check the authentic execution of the models. The authentic performance of the employed models is being verified from the k-fold crossvalidation process. In this method, the available data set is arranged randomly and split up into ten groups. A total of $60 \%$ of the dataset from total data points were used to train the model, $30 \%$ of the dataset were used to test the model, and $10 \%$ of the data were used for validation purposes. The process takes place in such a way that nine groups from ten are assigned for training the models, while the remaining one is for validation of the models. The said process was again repeated ten times to obtain the suitable average value. The K-fold cross-validation process also confirms the performance accuracy of the models. The statistical checks to confirm the accuracy level of the model's prediction were also employed using the equations illustrated below from (1)-(5)

$$
\begin{gathered}
\text { RMSE }=\sqrt{\frac{\sum_{i=1}^{n}\left(e x_{i}-m o_{i}\right)^{2}}{n}} \\
\text { MAE }=\frac{\sum_{i=1}^{n}\left|e x_{i}-m o_{i}\right|}{n} \\
\operatorname{RSE}=\frac{\sum_{i=1}^{n}\left(m o_{\left.i-e x_{i}\right)^{2}}\right.}{\sum_{i=1}^{n}\left(\overline{e x}-e x_{i}\right)^{2}} \\
R=\frac{\sum_{i=1}^{n}\left(e x_{i}-\overline{e x}_{i}\right)\left(m o_{i}-\overline{m o}_{i}\right)}{\sqrt{\sum_{i=1}^{n}\left(e x_{i}-\overline{e x_{i}}\right)^{2} \sum_{i=1}^{n}\left(m o_{i}-\overline{m o}_{i}\right)^{2}}}
\end{gathered}
$$

where,

$e x_{i}=$ experimental value,

$m o_{i}=$ predicted value,

$\overline{e x_{i}}=$ mean experimental value,

$\overline{m o}_{i}=$ mean predicted value obtained by the model,

$n=$ number of samples.

As seen in Figures 7-10, the coefficient correlation $\left(R^{2}\right)$, mean square error (MSE), mean absolute error (MAE), and root mean square error (RMSE) were used to evaluate the $k$-fold cross-validation of each employed model against its output. The variation was also noticed in the outcomes of both ML algorithms used (DT and AdaBoost). The lower the number of errors in the AdaBoost model, the higher the coefficient correlation $\left(R^{2}\right)$ value, indicating a higher accuracy level than the decision tree. The information obtained from the analysis for both CS and STS used for k-fold cross-validation is listed in Tables 3 and 4, respectively. 


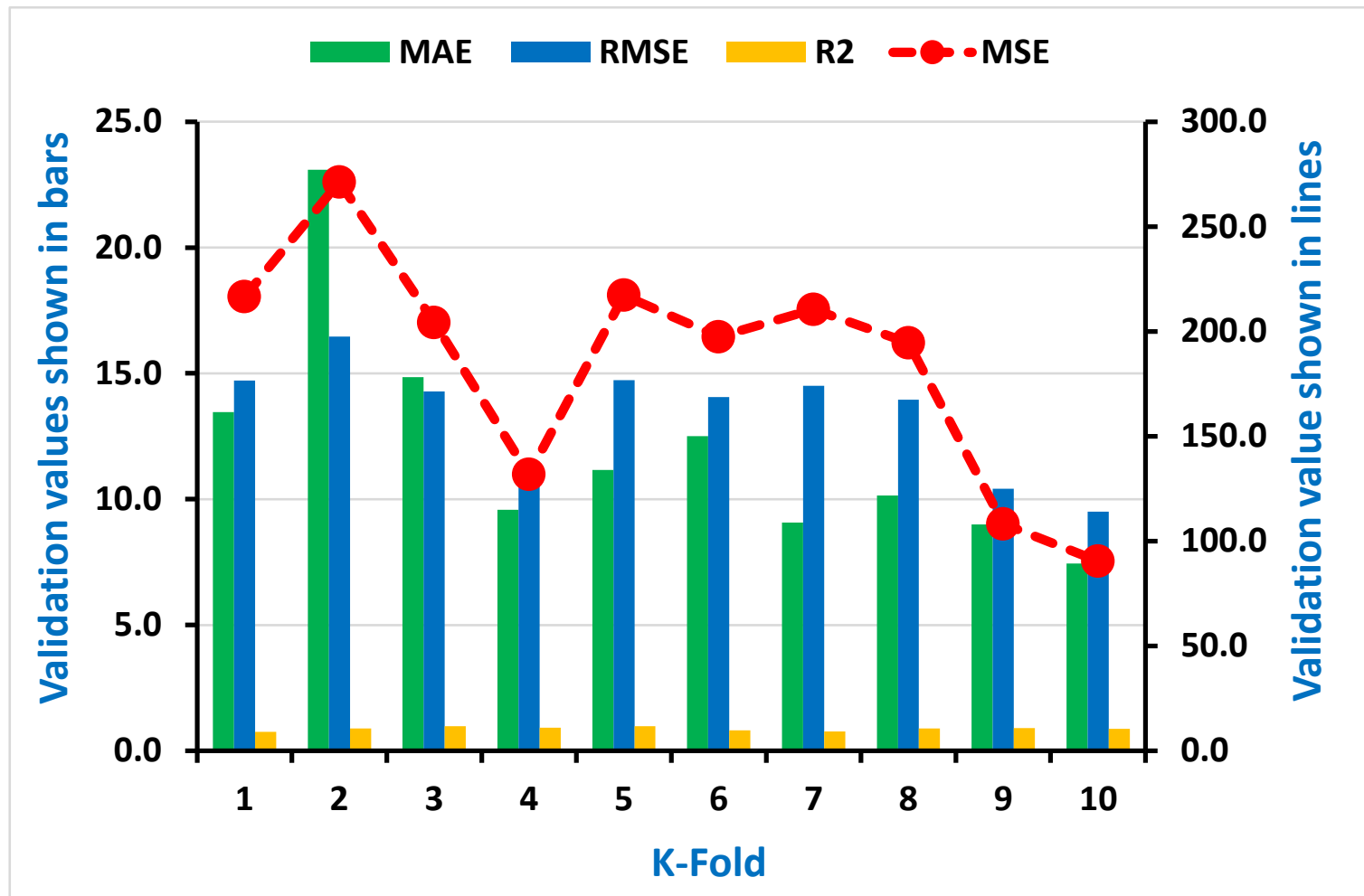

Figure 7. Representation of statistical information of k-fold cross-validation using DT for compressive strength.

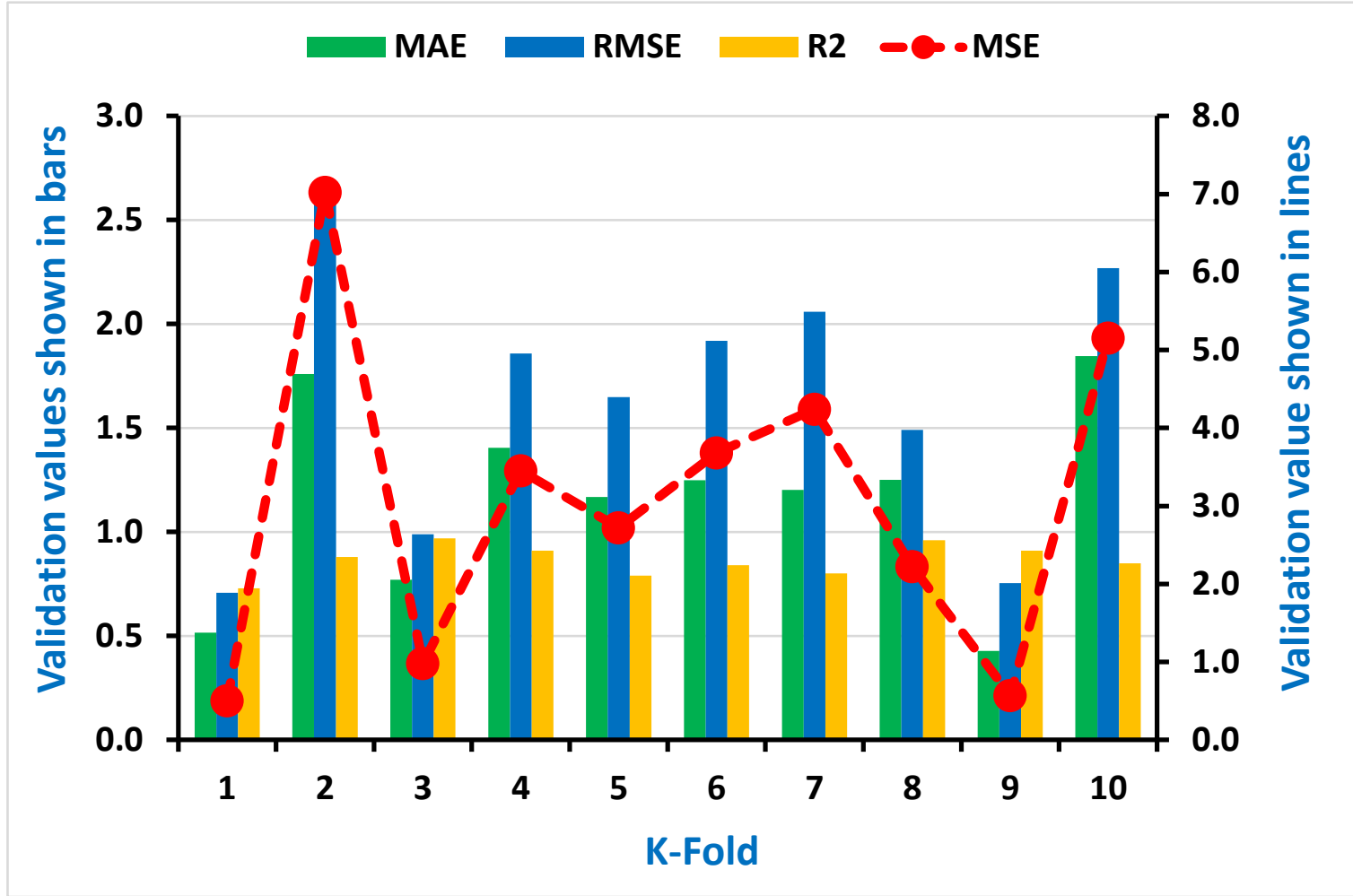

Figure 8. Representation of statistical information of k-fold cross-validation using DT for splitting tensile strength. 


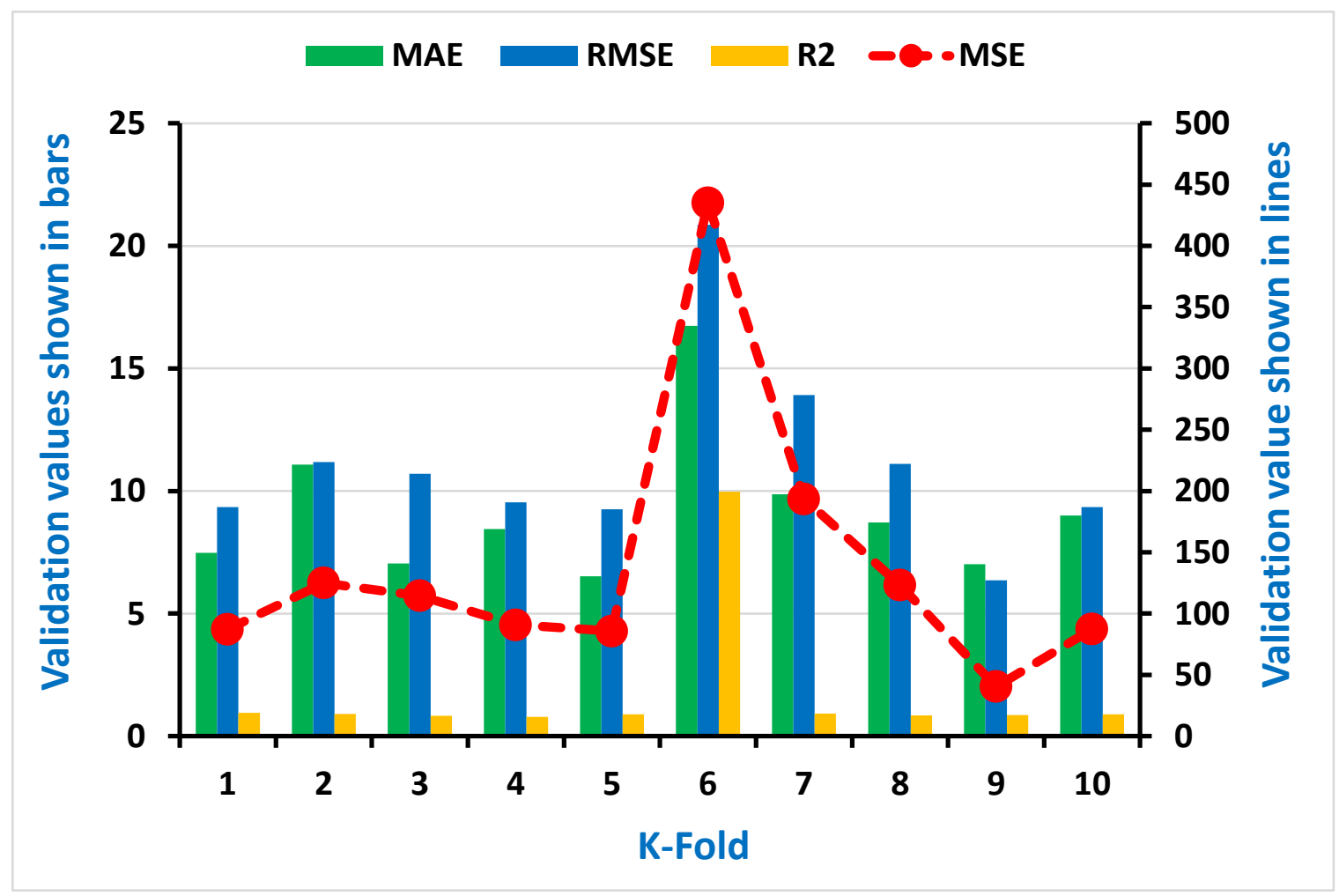

Figure 9. Representation of statistical information of k-fold cross-validation using AdaBoost for Compressive strength.

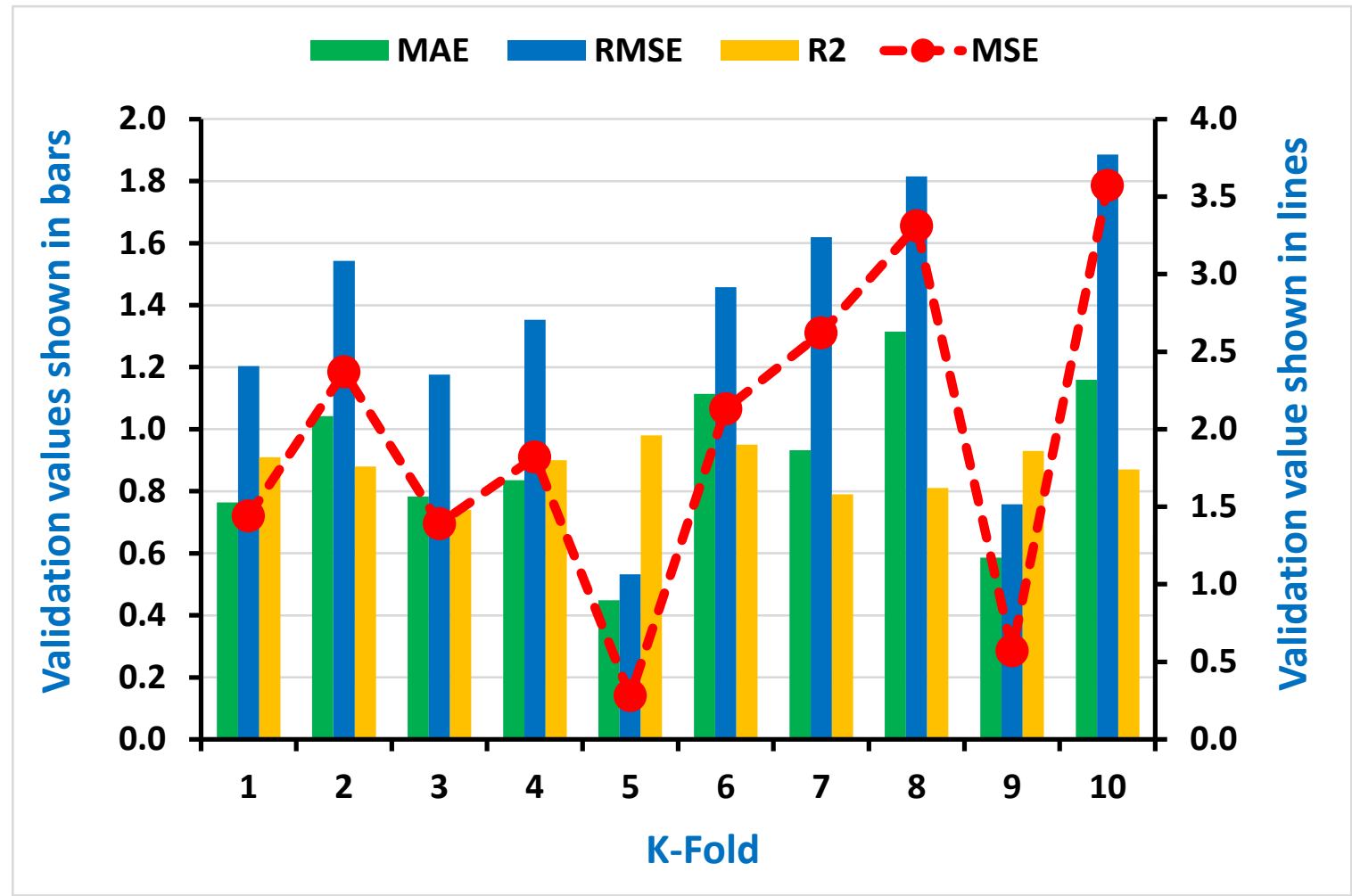

Figure 10. Representation of statistical information of k-fold cross-validation using AdaBoost for Splitting tensile strength. 
Table 3. Result of k-fold cross-validation for compressive strength.

\begin{tabular}{cccccccccc}
\hline \multicolumn{3}{c}{ AdaBoost } & \multicolumn{3}{c}{ Decision Tree } \\
\hline K-Fold & MAE & MSE & RMSE & $\mathbf{R}^{\mathbf{2}}$ & K-Fold & MAE & MSE & RMSE & $\mathbf{R}^{\mathbf{2}}$ \\
\hline 1 & 7.49 & 87.20 & 9.34 & 0.95 & 1 & 13.45 & 216.60 & 14.72 & 0.76 \\
2 & 11.08 & 124.99 & 11.18 & 0.91 & 2 & 23.10 & 271.26 & 16.47 & 0.89 \\
3 & 7.04 & 114.49 & 10.70 & 0.83 & 3 & 14.85 & 204.20 & 14.29 & 0.97 \\
4 & 8.45 & 90.82 & 9.53 & 0.79 & 4 & 9.59 & 131.79 & 11.48 & 0.92 \\
5 & 6.52 & 85.74 & 9.26 & 0.90 & 5 & 11.17 & 217.26 & 14.74 & 0.98 \\
6 & 16.74 & 435.13 & 20.86 & 9.98 & 6 & 12.51 & 197.40 & 14.05 & 0.82 \\
7 & 9.88 & 193.48 & 13.91 & 0.93 & 7 & 9.07 & 210.54 & 14.51 & 0.77 \\
8 & 8.72 & 123.43 & 11.11 & 0.85 & 8 & 10.15 & 194.60 & 13.95 & 0.88 \\
9 & 7.02 & 40.44 & 6.36 & 0.87 & 9 & 9.00 & 108.16 & 10.42 & 0.90 \\
10 & 9.00 & 87.42 & 9.35 & 0.90 & 10 & 7.44 & 90.44 & 9.51 & 0.87 \\
\hline
\end{tabular}

Table 4. Result of k-fold cross-validation for splitting tensile strength.

\begin{tabular}{cccccccccc}
\hline \multicolumn{3}{c}{ AdaBoost } & \multicolumn{5}{c}{ Decision Tree } \\
\hline K-Fold & MAE & MSE & RMSE & $\mathbf{R}^{\mathbf{2}}$ & K-Fold & MAE & MSE & RMSE $^{\mathbf{R}^{\mathbf{2}}}$ \\
\hline 1 & 0.76 & 1.44 & 1.20 & 0.91 & 1 & 0.52 & 0.50 & 0.71 & 0.73 \\
2 & 1.04 & 2.37 & 1.54 & 0.88 & 2 & 1.76 & 7.02 & 2.65 & 0.88 \\
3 & 0.78 & 1.39 & 1.18 & 0.74 & 3 & 0.77 & 0.98 & 0.99 & 0.97 \\
4 & 0.84 & 1.82 & 1.35 & 0.90 & 4 & 1.41 & 3.45 & 1.86 & 0.91 \\
5 & 0.45 & 0.28 & 0.53 & 0.98 & 5 & 1.17 & 2.72 & 1.65 & 0.79 \\
6 & 1.11 & 2.13 & 1.46 & 0.95 & 6 & 1.25 & 3.68 & 1.92 & 0.84 \\
7 & 0.93 & 2.62 & 1.62 & 0.79 & 7 & 1.20 & 4.24 & 2.06 & 0.80 \\
8 & 1.31 & 3.31 & 1.82 & 0.81 & 8 & 1.25 & 2.22 & 1.49 & 0.96 \\
9 & 0.59 & 0.57 & 0.76 & 0.93 & 9 & 0.43 & 0.57 & 0.75 & 0.91 \\
10 & 1.16 & 3.57 & 1.89 & 0.87 & 10 & 1.85 & 5.15 & 2.27 & 0.85 \\
\hline
\end{tabular}

Additionally, the information of statistical checks in the form of MAE, MSE, and RMSE were assessed for both CS and STS and can be seen in the Tables 5 and 6, respectively. The lesser error shows a higher coefficient correlation value $\left(\mathrm{R}^{2}\right)$.

Table 5. Statistical checks for compressive strength.

\begin{tabular}{cccc}
\hline Algorithms Used & MAE (MPa) & MSE (MPa) & RMSE (MPa) \\
\hline Decision tree (DT) & 3.58 & 11.02 & 3.32 \\
\hline AdaBoost & 2.33 & 7.8 & 2.79 \\
\hline
\end{tabular}

Table 6. Statistical checks for splitting tensile strength.

\begin{tabular}{cccc}
\hline Algorithm Used & MAE (MPa) & MSE (MPa) & RMSE (MPa) \\
\hline Decision tree (DT) & 0.31 & 0.29 & 0.54 \\
\hline AdaBoost & 0.30 & 0.20 & 0.45 \\
\hline
\end{tabular}

\section{Sensitivity Analyses}

The input variables have a remarkable effect on the execution of the model's outcome. The sensitivity analyses were done to investigate the effect of each variable on the anticipation of both STS and CS, as depicted in Figure 5. The cement significantly contributed $(36.8 \%)$ towards the prediction of CS, while other parameters contributed the least towards the forecasting of concrete CS containing RCA, as shown in Figure 11. However, the contribution of parameters for predicting the STS can be seen in Figure 12. The significant contributions for the prediction of the STS of concrete were cement $(41.2 \%)$ and natural 
coarse aggregate (NCA) (19\%), while superplasticizers and RCA were the next highest contributors for the prediction of outcomes. The equations mentioned below were used to calculate the contribution of each parameter towards the model's outcome.

$$
\begin{gathered}
N_{i}=f_{\max }\left(x_{i}\right)-f_{\min }\left(x_{i}\right) \\
S_{i}=\frac{N_{i}}{\sum_{j-i}^{n} N_{j}}
\end{gathered}
$$

where- $f_{\min }\left(x_{i}\right)$ and $f_{\max }\left(x_{i}\right)$ are the lower and higher of the estimated output over the $i$ th output.

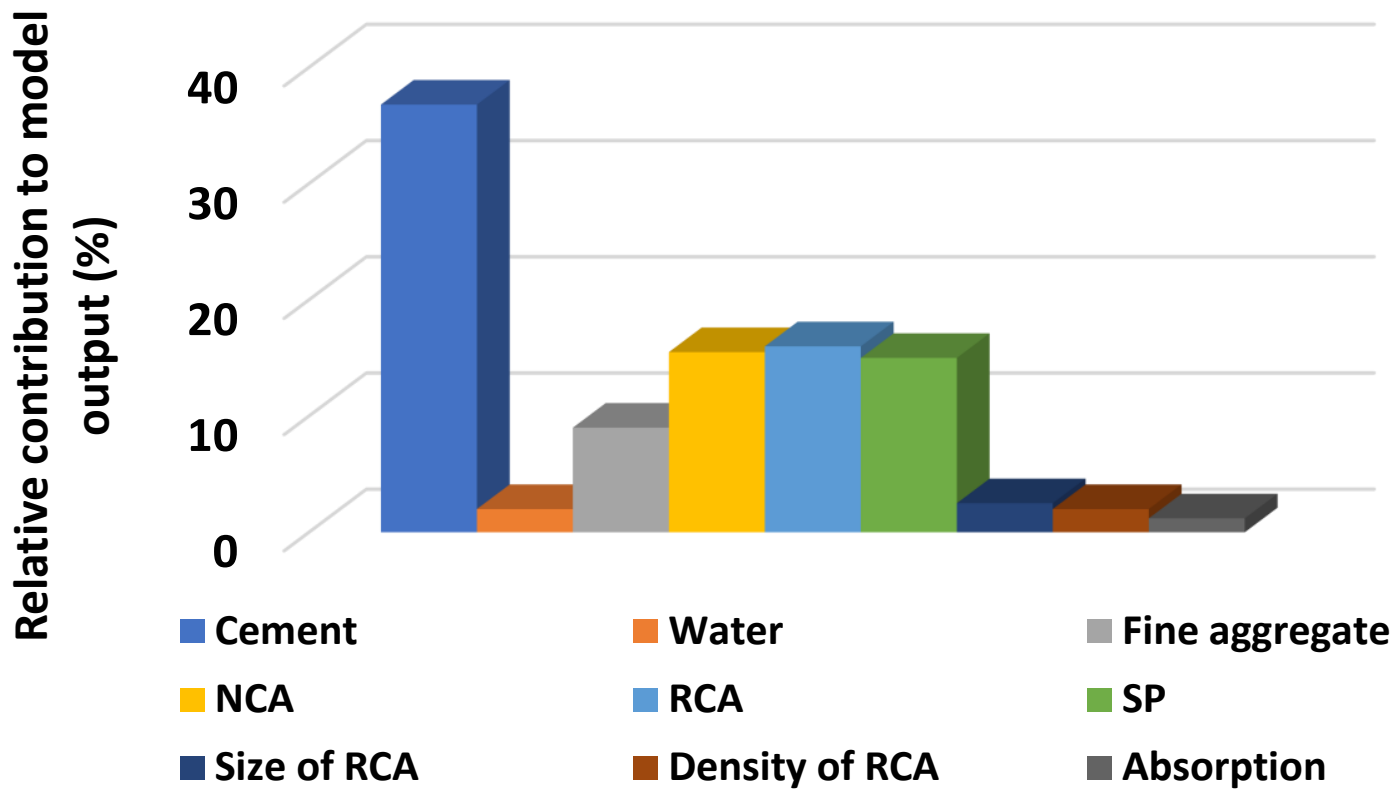

Figure 11. Contributing level of the input variables towards the prediction of output for CS.

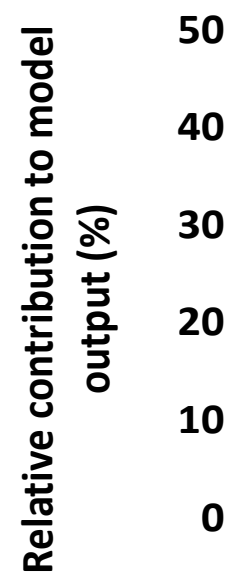

Cement

NCA

Size of RCA

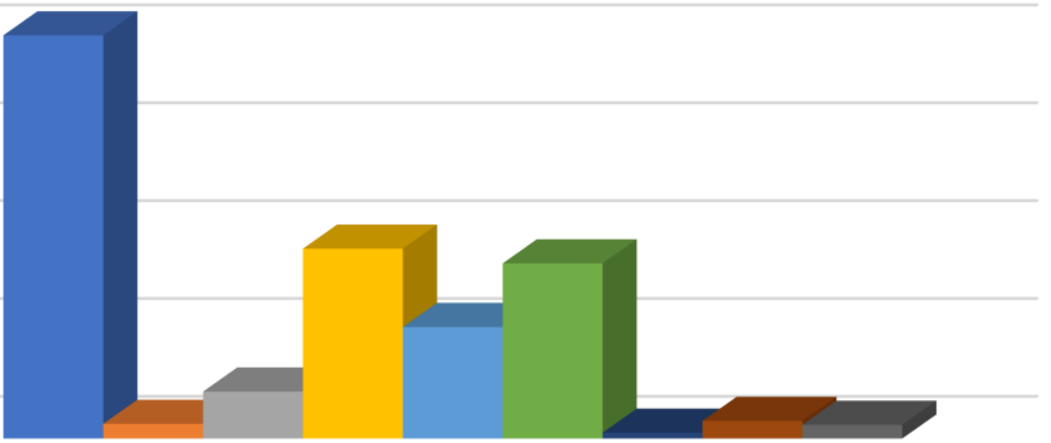

Figure 12. Contributing level of the input variables towards the prediction of output for STS. 


\section{Discussion}

As demonstrated by the data, the ML-based strategy for forecasting the mechanical characteristics of concrete is clearly better than traditional mechanics-based methods. The advantages are as follows: (1) ML does not at all require complex mechanics/theoretical equations but instead finds the mapping between the input and output utilizing numerical and/or computer knowledge of science, making it very accessible to the readers; (2) Unlike most empirical models, which typically consider a limited number of variables when deriving the formula, ML can consider an infinite number of variables; (3) Meanwhile, inherent uncertainties [55] can be incorporated into the training process; and (4) The precision, reliability, and robustness of machine learning-based models are significantly higher than those of traditional models: they can provide objective and accurate results in a matter of seconds.

The research approach of this study was to predict the mechanical properties (CS and STS) of concrete containing recycled coarse aggregates (RCA) via supervised machine learning algorithms. The anaconda navigator software was used to incorporate the Python coding for each employed machine learning algorithm. An excel file having a relevant database was used in the software, which allowed it to show the output results in the form of $\mathrm{R}^{2}, \mathrm{MAE}$, MSE, and RMSE. The AdaBoost technique performs well, as proven by the coefficient correlation $\left(\mathrm{R}^{2}\right)$ value of 0.95 for CS prediction and 0.92 for STS prediction., Feng et al. [56] Additionally, AdaBoost was used to classify failure modes, yielding an accuracy of 0.96 , and to determine the bearing capacity of reinforced concrete, yielding an $\mathrm{R}^{2}$ value of 0.98 . However, the value of $\mathrm{R}^{2}$ for DT in predicting the CS was 0.93 , and in forecasting, the STS was equal to 0.90. In comparison, Ahmad et al. [57] also employed DT to predict the CS of geopolymer concrete, which shows a reasonable and almost similar value of $R^{2}$ equal to 0.90 for its outcome. The higher value of $R^{2}(0.95$ for compressive and 0.92 for STS) for AdaBoost indicates the high performance towards the prediction of the outcomes as compared to the $\mathrm{R}^{2}$ value for DT ( 0.93 for compressive and 0.90 for STS). The lesser values of each error (MAE, MSE, RMSE) for AdaBoost also confirm the model's better accuracy level as opposed to the errors values for the DT. In addition, the sensitivity analysis describes the contribution level of each parameter used to run the model for predicting the mechanical properties of concrete containing recycled coarse aggregates. Cement and natural coarse aggregate (NCA) contributed significantly, up to $41.2 \%$ and $19 \%$, respectively, while superplasticizers and RCA were the next highest contributors for the prediction of outcomes. It was noted that the accuracy level of the ensemble machine learning approach (AdaBoost) was higher than the individual machine learning technique (DT).

\section{Conclusions and Future Recommendations}

This research describes the application of both individual and ensemble ML algorithms to forecast the mechanical properties such as compressive strength (CS) and splitting tensile strength (STS) of concrete having recycled coarse aggregate (RCA). The decision tree (DT) and AdaBoost approaches were incorporated for prediction purposes. The input variables were analyzed by indicating their relative frequency distribution. The Python coding was used in the Spyder (Anaconda software) to run the required models for further investigation. The statistical checks in the form of various errors (MAE, RMSE, MSE) were evaluated to confirm the accuracy of each employed model. However, the k-fold cross-validation method was also included in the study for the confirmation of the model's accuracy. In addition, the contribution of each input variable was investigated via sensitivity analysis. The following conclusions and future recommendations can be drawn from the study.

- The ensemble machine learning algorithm (AdaBoost) shows a better response with less variance towards the prediction of both the CS and splitting tensile strength of RCA-based concrete.

- The AdaBoost regressor gives the values of coefficient correlation $\left(\mathrm{R}^{2}\right)$ for CS and STS of concrete equal to 0.95 and 0.92 , respectively, as opposed to the values of $R^{2}$ for DT equal to 0.93 (CS) and 0.90 (STS). 
- The higher values of $\mathrm{R}^{2}$ for the AdaBoost regressor towards the prediction of both CS and STS indicate the high accuracy of the model.

- From the statistical checks, the lesser value of the errors (MAE, MSE, RMSE) also indicates high performance for the AdaBoost approach compared to the DT algorithm.

- The K-fold cross-validation method also confirms the high accuracy level of the AdaBoost algorithm.

- Sensitivity analysis reveals that the cement contributed effectively (32\%) as compared to other parameters towards the forecasting of the CS of RCA-based concrete, while the superplasticizers were the higher contributor towards the prediction of the STS of concrete containing RCA.

In conclusion, this study was based on the application of supervised machine learning (ML) algorithms to foretell the two parameters (CS and STS) of concrete having recycled coarse aggregate (RCA). It also gives an idea of the importance of multiple aspects like the input variables, the number of data points for running the models, and the types of ML approaches to be used for high accuracy of the outcomes. The algorithms employed in this study show a strong relationship between the actual and predicted output. The importance of these approaches in civil engineering is indicated by their high accuracy level among the real and forecasted results. The supervised ML approaches are gaining more popularity, as their application gives high accuracy results/outcomes and minimizes the physical approach of the practical work and total cost of the project. Additionally, it is essential to incorporate laboratory work to compare machine learning approaches' findings to better understand their effectiveness. Additionally, the data points, type of material used, size of specimens, environmental conditions, curing conditions, loading rate, and increase in the input parameters can be modified or added to study and compare the results of various machine learning algorithms. Moreover, various ML techniques such as artificial neural networks (ANN), support vector machines (SVM), and boosting can be included to evaluate their performance.

Author Contributions: M.S.—conceptualization, writing-original draft, and validation; H.L.—data curation, formal analysis, and writing - review \& editing; A.A.—software and writing-review \& editing; W.A.—data curation and writing — review \& editing; K.A.O.—project administration and supervision; F.A.—resources and writing-review \& editing; P.J.-formal analysis and investigation; T.M.M.-visualization and writing-review \& editing. All authors have read and agreed to the published version of the manuscript.

Funding: This research was funded by Cracow University of Technology.

Institutional Review Board Statement: Not applicable.

Informed Consent Statement: Not applicable.

Data Availability Statement: Not applicable.

Conflicts of Interest: The authors declare no conflict of interest.

Appendix A

\begin{tabular}{|c|c|c|c|c|c|c|c|c|c|c|}
\hline $\begin{array}{c}\text { Water } \\
\left(\mathrm{kg} / \mathrm{m}^{3}\right)\end{array}$ & $\begin{array}{l}\text { Cement } \\
\left(\mathrm{kg} / \mathrm{m}^{3}\right)\end{array}$ & $\begin{array}{c}\text { Sand } \\
\left(\mathrm{kg} / \mathrm{m}^{3}\right)\end{array}$ & $\begin{array}{c}\text { NCA } \\
\left(\mathrm{kg} / \mathrm{m}^{3}\right)\end{array}$ & $\begin{array}{c}\text { RCA } \\
\left(\mathrm{kg} / \mathrm{m}^{3}\right)\end{array}$ & $\begin{array}{c}\mathrm{SP} \\
\left(\mathrm{kg} / \mathrm{m}^{3}\right)\end{array}$ & $\begin{array}{c}\text { RCA } \\
\text { Size } \\
\left(\mathrm{kg} / \mathrm{m}^{3}\right)\end{array}$ & $\begin{array}{l}\text { Density } \\
\left(\mathrm{kg} / \mathrm{m}^{3}\right)\end{array}$ & $\begin{array}{c}\text { Absorption } \\
(\%)\end{array}$ & $\begin{array}{c}\text { CS } \\
(\mathrm{MPa})\end{array}$ & $\begin{array}{c}\text { STS } \\
\text { (MPa) }\end{array}$ \\
\hline 165 & 370 & 650 & 850.5 & 364.5 & 2.22 & 20 & 2400 & 4.9 & 50.6 & - \\
\hline 165 & 370 & 650 & 607.5 & 607.5 & 2.22 & 20 & 2400 & 4.9 & 50.8 & - \\
\hline 165 & 370 & 650 & - & 1215 & 2.22 & 20 & 2400 & 4.9 & 50.2 & - \\
\hline 165 & 460 & 575 & 850.5 & 364.5 & 2.22 & 20 & 2400 & 4.9 & 60.8 & - \\
\hline 165 & 460 & 575 & 607.5 & 607.5 & 2.22 & 20 & 2400 & 4.9 & 61.2 & - \\
\hline
\end{tabular}




\begin{tabular}{|c|c|c|c|c|c|c|c|c|c|c|}
\hline $\begin{array}{c}\text { Water } \\
\left(\mathrm{kg} / \mathrm{m}^{3}\right)\end{array}$ & $\begin{array}{l}\text { Cement } \\
\left(\mathrm{kg} / \mathrm{m}^{3}\right)\end{array}$ & $\begin{array}{c}\text { Sand } \\
\left(\mathrm{kg} / \mathrm{m}^{3}\right)\end{array}$ & $\begin{array}{c}\text { NCA } \\
\left(\mathrm{kg} / \mathrm{m}^{3}\right)\end{array}$ & $\begin{array}{c}\text { RCA } \\
\left(\mathrm{kg} / \mathrm{m}^{3}\right)\end{array}$ & $\begin{array}{c}\mathrm{SP} \\
\left(\mathrm{kg} / \mathrm{m}^{3}\right)\end{array}$ & $\begin{array}{c}\text { RCA } \\
\text { Size } \\
\left(\mathrm{kg} / \mathrm{m}^{3}\right)\end{array}$ & $\begin{array}{l}\text { Density } \\
\left(\mathrm{kg} / \mathrm{m}^{3}\right)\end{array}$ & $\begin{array}{c}\text { Absorption } \\
(\%)\end{array}$ & $\begin{array}{c}\text { CS } \\
(\mathrm{MPa})\end{array}$ & $\begin{array}{c}\text { STS } \\
\text { (MPa) }\end{array}$ \\
\hline 165 & 460 & 575 & - & 1215 & 2.22 & 20 & 2400 & 4.9 & 60.2 & - \\
\hline 165 & 560 & 495 & 850.5 & 364.5 & 2.59 & 20 & 2400 & 4.9 & 70.2 & - \\
\hline 165 & 560 & 495 & 607.5 & 607.5 & 2.59 & 20 & 2400 & 4.9 & 70.8 & - \\
\hline 165 & 560 & 495 & - & 1215 & 2.59 & 20 & 2400 & 4.9 & 70 & - \\
\hline 180 & 500 & 486.6 & - & 1135.4 & - & 16 & - & - & 44.5 & 4 \\
\hline 180 & 500 & - & - & 1574.3 & - & 16 & - & - & 38.7 & 3.5 \\
\hline 180 & 500 & 486.6 & - & 1135.4 & - & 16 & - & - & 46.1 & 3.4 \\
\hline 180 & 500 & - & - & 1574.3 & - & 16 & - & - & 42.4 & 3.2 \\
\hline 180 & 500 & 486.6 & - & 1135.4 & - & 16 & - & - & 52.5 & 4 \\
\hline 180 & 500 & - & - & 1574.3 & - & 16 & - & - & 50.7 & 3.6 \\
\hline 180 & 500 & 486.6 & - & 1135.4 & - & 16 & - & - & 45.2 & 3.5 \\
\hline 180 & 500 & - & - & 1574.3 & - & 16 & - & - & 42 & 3.2 \\
\hline 180 & 500 & 486.6 & - & 1135.4 & - & 16 & - & - & 49.6 & 3.8 \\
\hline 180 & 500 & - & - & 1574.3 & - & 16 & - & - & 45.1 & 3.5 \\
\hline 180 & 500 & 509.6 & - & 1135.4 & - & 16 & - & - & 54.4 & 4 \\
\hline 180 & 500 & - & - & 1574.3 & - & 16 & - & - & 48.2 & 3.8 \\
\hline 207.6 & 400 & 662 & 863 & 153 & - & 20 & 2410 & 5.8 & 38.1 & 3.7 \\
\hline 207.6 & 400 & 662 & 697 & 298 & - & 20 & 2410 & 5.8 & 37 & 3.6 \\
\hline 207.6 & 400 & 662 & 383 & 573 & - & 20 & 2410 & 5.8 & 35.8 & 3.4 \\
\hline 207.6 & 400 & 662 & - & 903 & - & 20 & 2410 & 5.8 & 34.5 & 3.3 \\
\hline 217 & 353 & 660 & 861 & 209 & - & 20 & 2330 & 6.3 & 44.9 & - \\
\hline 229 & 353 & 647 & 527 & 513 & - & 20 & 2330 & 6.3 & 44.7 & - \\
\hline 241 & 353 & 625 & - & 993 & - & 20 & 2330 & 6.3 & 46.8 & - \\
\hline 230 & 353 & 661 & 853 & 202 & - & 20 & 2330 & 6.3 & 43.2 & - \\
\hline 247 & 353 & 647 & 524 & 496 & - & 20 & 2330 & 6.3 & 39.7 & - \\
\hline 271 & 353 & 625 & - & 959 & - & 20 & 2330 & 6.3 & 43.3 & - \\
\hline 206 & 353 & 661 & 864 & 216 & - & 20 & 2330 & 6.3 & 43 & - \\
\hline 207 & 353 & 649 & 531 & 531 & - & 20 & 2330 & 6.3 & 38.1 & - \\
\hline 165 & 300 & 765 & 905 & 267 & 4.98 & 25 & 2430 & 4.4 & 42 & 3 \\
\hline 165 & 318 & 739 & 608 & 537 & 6.042 & 25 & 2430 & 4.4 & 41 & 3.2 \\
\hline 162 & 325 & 683 & - & 1123 & 6.175 & 25 & 2430 & 4.4 & 40 & 3.2 \\
\hline 160.6 & 380 & 598 & 1182 & 52 & 4.9 & 20 & 2165 & 6.8 & 62.2 & - \\
\hline 165.4 & 380 & 529 & 1175 & 103 & 4.9 & 20 & 2165 & 6.8 & 58.4 & - \\
\hline 170.2 & 380 & 460 & 1168 & 154 & 4.9 & 20 & 2165 & 6.8 & 61.3 & 3.7 \\
\hline 175.6 & 380 & 327 & 1162 & 254 & 4.9 & 20 & 2165 & 6.8 & 60.8 & - \\
\hline 180.9 & 380 & - & 1162 & 509 & 4.9 & 20 & 2165 & 6.8 & 61 & 3 \\
\hline 225 & 410 & 642 & 840 & 204 & - & 20 & 2570 & 3.5 & 45.3 & - \\
\hline 225 & 410 & 642 & 524 & 506 & - & 20 & 2570 & 3.5 & 42.5 & - \\
\hline 225 & 410 & 642 & 210 & 814 & - & 20 & 2570 & 3.5 & 39.2 & - \\
\hline 225 & 410 & 642 & - & 1017 & - & 20 & 2570 & 3.5 & 37.1 & - \\
\hline 180 & 400 & 708 & 886 & 215 & - & 20 & 2570 & 3.5 & 62.4 & 3.2 \\
\hline 180 & 400 & 708 & 554 & 538 & - & 20 & 2570 & 3.5 & 55.8 & 3 \\
\hline 180 & 400 & 708 & - & 1075 & - & 20 & 2570 & 3.5 & 42 & 2.8 \\
\hline 225 & 410 & 642 & 840 & 204 & - & 20 & 2570 & 3.5 & 45.3 & 3.2 \\
\hline 225 & 410 & 642 & 524 & 506 & - & 20 & 2570 & 3.5 & 42.5 & 3.2 \\
\hline 225 & 410 & 642 & - & 1017 & - & 20 & 2570 & 3.5 & 38.1 & 3.1 \\
\hline 234 & 360 & 705 & - & 1100 & - & 19 & 2390 & 4.4 & 22.1 & - \\
\hline 190 & 380 & 705 & - & 1100 & - & 19 & 2390 & 4.4 & 25.1 & - \\
\hline 192 & 400 & 705 & - & 1100 & - & 19 & 2390 & 4.4 & 27.2 & - \\
\hline 181 & 420 & 705 & - & 1100 & - & 19 & 2390 & 4.4 & 28.7 & - \\
\hline 184 & 460 & 705 & - & 1100 & - & 19 & 2390 & 4.4 & 29.5 & - \\
\hline 178 & 264 & 835 & - & 1030 & - & 30 & 2520 & 3.8 & 18 & - \\
\hline 174 & 262 & 830 & - & 1020 & - & 30 & 2510 & 3.9 & 15.4 & - \\
\hline 148 & 427 & 760 & - & 1000 & 4.2 & 30 & 2520 & 3.8 & 36.4 & - \\
\hline 153 & 423 & 755 & - & 990 & 4.1 & 30 & 2510 & 3.9 & 35.7 & - \\
\hline 152 & 443 & 855 & - & 885 & 3.9 & 30 & 2520 & 3.8 & 44.4 & - \\
\hline 225 & 410 & 642 & 840 & 204 & - & 20 & 2580 & 3.5 & 45.3 & 3.6 \\
\hline
\end{tabular}




\begin{tabular}{|c|c|c|c|c|c|c|c|c|c|c|}
\hline $\begin{array}{c}\text { Water } \\
\left(\mathrm{kg} / \mathrm{m}^{3}\right)\end{array}$ & $\begin{array}{l}\text { Cement } \\
\left(\mathrm{kg} / \mathrm{m}^{3}\right)\end{array}$ & $\begin{array}{c}\text { Sand } \\
\left(\mathrm{kg} / \mathrm{m}^{3}\right)\end{array}$ & $\begin{array}{c}\text { NCA } \\
\left(\mathrm{kg} / \mathrm{m}^{3}\right)\end{array}$ & $\begin{array}{c}\text { RCA } \\
\left(\mathrm{kg} / \mathrm{m}^{3}\right)\end{array}$ & $\begin{array}{c}\mathrm{SP} \\
\left(\mathrm{kg} / \mathrm{m}^{3}\right)\end{array}$ & $\begin{array}{c}\text { RCA } \\
\text { Size } \\
\left(\mathrm{kg} / \mathrm{m}^{3}\right)\end{array}$ & $\begin{array}{l}\text { Density } \\
\left(\mathrm{kg} / \mathrm{m}^{3}\right)\end{array}$ & $\begin{array}{c}\text { Absorption } \\
(\%)\end{array}$ & $\begin{array}{c}\mathrm{CS} \\
(\mathrm{MPa})\end{array}$ & $\begin{array}{l}\text { STS } \\
\text { (MPa) }\end{array}$ \\
\hline 225 & 410 & 642 & 524 & 506 & - & 20 & 2580 & 3.5 & 42.5 & 3.4 \\
\hline 225 & 410 & 642 & - & 1017 & - & 20 & 2580 & 3.5 & 38.1 & 3.3 \\
\hline 205 & 410 & 662 & 865 & 210 & - & 20 & 2580 & 3.5 & 51.7 & 3.6 \\
\hline 205 & 410 & 662 & 541 & 525 & - & 20 & 2580 & 3.5 & 47.1 & 3.6 \\
\hline 205 & 410 & 662 & - & 1049 & - & 20 & 2580 & 3.5 & 43.4 & 3.4 \\
\hline 180 & 400 & 708 & 886 & 215 & 5.6 & 20 & 2580 & 3.5 & 62.4 & 3.7 \\
\hline 180 & 400 & 708 & 554 & 538 & 5.6 & 20 & 2580 & 3.5 & 56.8 & 3.7 \\
\hline 180 & 400 & 708 & - & 1075 & 5.6 & 20 & 2580 & 3.5 & 52.1 & 3.5 \\
\hline 160 & 400 & 729 & 912 & 221 & 7.8 & 20 & 2580 & 3.5 & 69.6 & 4.1 \\
\hline 160 & 400 & 729 & 570 & 554 & 7.8 & 20 & 2580 & 3.5 & 65.3 & 4 \\
\hline 160 & 400 & 729 & - & 1107 & 7.8 & 20 & 2580 & 3.5 & 58.5 & 3.8 \\
\hline 175 & 350 & 730 & 711 & 297 & 1.68 & 25 & 2530 & 1.9 & 36.7 & 4.2 \\
\hline 175 & 350 & 730 & 508 & 494 & 1.68 & 25 & 2530 & 1.9 & 38 & 4 \\
\hline 175 & 350 & 730 & - & 989 & 1.68 & 25 & 2530 & 1.9 & 36 & 3.8 \\
\hline 175 & 350 & 730 & 711 & 282 & 1.68 & 25 & - & - & 32.6 & 3.6 \\
\hline 175 & 350 & 730 & 508 & 469 & 1.68 & 25 & 2400 & 6.2 & 30.4 & 3.4 \\
\hline 175 & 350 & 730 & - & 938 & 1.68 & 25 & 2400 & 6.2 & 29.5 & 3.2 \\
\hline 190 & 380 & 744.45 & 756.97 & 189.24 & 2.66 & 20 & 2338 & 5.2 & 47.4 & - \\
\hline 190 & 380 & 709.54 & 471.13 & 471.12 & 2.66 & 20 & 2338 & 5.2 & 47.3 & - \\
\hline 190 & 380 & 714.56 & - & 874.04 & 5.32 & 20 & 2338 & 5.2 & 54.8 & - \\
\hline 140 & 350 & 732 & 519 & 556 & 4.2 & 12 & 2420 & 6.8 & 43.3 & - \\
\hline 153 & 340 & 723 & 512 & 549 & 3.4 & 12 & 2400 & 6.8 & 39.6 & - \\
\hline 165 & 330 & 715 & 507 & 543 & 2.64 & 12 & 2400 & 6.8 & 38.1 & - \\
\hline 176 & 320 & 708 & 502 & 537 & 1.92 & 12 & 2400 & 6.8 & 34.5 & - \\
\hline 186 & 310 & 702 & 497 & 533 & 1.24 & 12 & 2400 & 6.8 & 31.6 & - \\
\hline 140 & 350 & 732 & 553 & 523 & 4.2 & 22 & 2420 & 8.8 & 46.1 & - \\
\hline 153 & 340 & 723 & 547 & 517 & 3.4 & 22 & 2420 & 8.8 & 45.8 & - \\
\hline 165 & 330 & 715 & 541 & 511 & 2.64 & 22 & 2420 & 8.8 & 39.9 & - \\
\hline 176 & 320 & 708 & 535 & 506 & 1.92 & 22 & 2420 & 8.8 & 36.3 & - \\
\hline 186 & 310 & 702 & 531 & 501 & 1.24 & 22 & 2420 & 8.8 & 34.7 & - \\
\hline 186 & 372 & 617.65 & 1030.22 & 257.56 & - & 20 & 2400 & - & 27.2 & 3.1 \\
\hline 186 & 372 & 617.65 & 772.67 & 515.55 & - & 20 & 2400 & - & 26.5 & 2.8 \\
\hline 186 & 372 & 617.65 & 515.11 & 772.67 & - & 20 & 2400 & - & 25.4 & 2.7 \\
\hline 186 & 372 & 617.65 & 257.56 & 1030.22 & - & 20 & 2400 & - & 25.1 & 2.2 \\
\hline 186 & 372 & 494.12 & 128.78 & 123.53 & - & 20 & 2630 & - & 26.4 & 2.6 \\
\hline 186 & 372 & 370.59 & 128.78 & 247.06 & - & 20 & 2630 & - & 25.9 & 2.5 \\
\hline 186 & 372 & 247.06 & 128.78 & 370.59 & - & 20 & 2630 & - & 23.5 & 2.3 \\
\hline 186 & 372 & 123.53 & 128.78 & 494.12 & - & 20 & 2630 & - & 15.4 & 2 \\
\hline 200 & 270 & 750 & 675 & 200 & 1.08 & 19 & 2440 & 5.8 & 18.5 & 1.9 \\
\hline 210 & 270 & 750 & 450 & 400 & 1.35 & 19 & 2440 & 5.8 & 18 & 1.9 \\
\hline 220 & 270 & 750 & 225 & 600 & 1.62 & 19 & 2440 & 5.8 & 16.5 & 1.4 \\
\hline 165 & 370 & 865 & 760 & 230 & 1.48 & 19 & 2440 & 5.8 & 33 & 3.1 \\
\hline 165 & 370 & 865 & 505 & 455 & 1.85 & 19 & 2440 & 5.8 & 34.5 & 3.1 \\
\hline 165 & 370 & 865 & 250 & 680 & 2.59 & 19 & 2440 & 5.8 & 34 & 2.9 \\
\hline 178.5 & 275 & 938.05 & 723.07 & 180.77 & 1.925 & 16 & 2400 & 5 & 31.7 & 2.4 \\
\hline 178.5 & 275 & 962.73 & 423.77 & 423.77 & 1.925 & 16 & 2400 & 5 & 32.4 & 2.5 \\
\hline 178.5 & 275 & 1005.18 & - & 756.46 & 1.925 & 16 & 2400 & 5 & 30.1 & 2.6 \\
\hline 190 & 380 & 794.31 & 750.04 & 187.57 & 2.66 & 16 & 2400 & 5 & 43.7 & 3.1 \\
\hline 190 & 380 & 811.37 & 443.71 & 443.71 & 2.66 & 16 & 2400 & 5 & 37.5 & 2.9 \\
\hline 190 & 380 & 838.29 & - & 807.97 & 2.66 & 16 & 2400 & 5 & 40.5 & 2.9 \\
\hline 151 & 335 & 630 & 414 & 720 & 1.266 & 19 & 2420 & 5.4 & 41.4 & - \\
\hline 156 & 349 & 888 & - & 792 & 1.67616 & 19 & 2420 & 5.4 & 43.9 & - \\
\hline 161 & 358 & 645 & 281 & 813 & 1.3584 & 19 & 2500 & 3.3 & 44.8 & - \\
\hline 156 & 349 & 857 & - & 867 & 1.2564 & 19 & 2500 & 3.3 & 45.9 & - \\
\hline 172.43 & 401 & 574 & 911 & 303 & 0.2005 & 20 & 2661 & 1.9 & 47 & 2.3 \\
\hline 172.43 & 401 & 574 & 585 & 585 & 0.70175 & 20 & 2602 & 2.6 & 46 & 2.1 \\
\hline
\end{tabular}




\begin{tabular}{|c|c|c|c|c|c|c|c|c|c|c|}
\hline $\begin{array}{c}\text { Water } \\
\left(\mathrm{kg} / \mathrm{m}^{3}\right)\end{array}$ & $\begin{array}{l}\text { Cement } \\
\left(\mathrm{kg} / \mathrm{m}^{3}\right)\end{array}$ & $\begin{array}{c}\text { Sand } \\
\left(\mathrm{kg} / \mathrm{m}^{3}\right)\end{array}$ & $\begin{array}{c}\text { NCA } \\
\left(\mathrm{kg} / \mathrm{m}^{3}\right)\end{array}$ & $\begin{array}{c}\text { RCA } \\
\left(\mathrm{kg} / \mathrm{m}^{3}\right)\end{array}$ & $\begin{array}{c}\mathrm{SP} \\
\left(\mathrm{kg} / \mathrm{m}^{3}\right)\end{array}$ & $\begin{array}{c}\text { RCA } \\
\text { Size } \\
\left(\mathrm{kg} / \mathrm{m}^{3}\right)\end{array}$ & $\begin{array}{l}\text { Density } \\
\left(\mathrm{kg} / \mathrm{m}^{3}\right)\end{array}$ & $\begin{array}{c}\text { Absorption } \\
(\%)\end{array}$ & $\begin{array}{c}\text { CS } \\
(\mathrm{MPa})\end{array}$ & $\begin{array}{c}\text { STS } \\
\text { (MPa) }\end{array}$ \\
\hline 172.43 & 401 & 574 & - & 1119 & 0.90225 & 20 & 2510 & 3.9 & 42.5 & 2 \\
\hline 190.8 & 424 & 770 & - & 980 & - & 19 & 2490 & 4.8 & 41 & - \\
\hline 192.5 & 350 & 800 & - & 1015 & - & 19 & 2490 & 4.8 & 33.3 & - \\
\hline 191.75 & 295 & 814 & - & 1039 & - & 19 & 2490 & 4.8 & 24.8 & - \\
\hline 150 & 250 & 762 & 858 & 286 & 4.375 & 19 & - & - & 26.7 & 2.2 \\
\hline 150 & 250 & 753 & 564 & 564 & 4.375 & 19 & - & - & 21.5 & 1.8 \\
\hline 150 & 250 & 743 & 279 & 836 & 4.375 & 19 & - & - & 21.4 & 1.4 \\
\hline 150 & 250 & 734 & - & 1100 & 4.375 & 19 & - & - & 20 & 1.2 \\
\hline 180 & 400 & 685 & 770 & 257 & 3 & 19 & - & - & 38.3 & 3.1 \\
\hline 180 & 400 & 676 & 507 & 507 & 3 & 19 & - & - & 37 & 2.7 \\
\hline 180 & 400 & 667 & 250 & 751 & 3 & 19 & - & - & 35 & 2.5 \\
\hline 180 & 400 & 659 & - & 988 & 3 & 19 & - & - & 33.3 & 2.1 \\
\hline 175 & 325 & - & - & 1762 & 3.45 & 32 & 2263 & 6 & 33.2 & - \\
\hline 222 & 350 & - & - & 1778 & 4.5 & 32 & 2283 & 4.2 & 35.6 & - \\
\hline 221 & 350 & - & - & 1771 & 4.5 & 32 & 2292 & 4.3 & 34.6 & - \\
\hline 195 & 325 & - & - & 1710 & 3.25 & 32 & 2301 & 5 & 37.3 & - \\
\hline 123 & 300 & - & 192 & 1728 & 3 & 32 & 2609 & 1.5 & 45.4 & - \\
\hline 144 & 325 & - & 768 & 1152 & 3.25 & 32 & 2518 & 2.7 & 54.3 & - \\
\hline 123 & 325 & - & 754.4 & 1131.6 & 3.25 & 32 & 2584 & 1.6 & 54.4 & - \\
\hline 132 & 300 & - & 1448.25 & 482.75 & 3 & 32 & 2594 & 1.6 & 53.4 & - \\
\hline 180 & 275 & 625 & 882 & 378 & - & 20 & 2340 & 5.3 & 20 & - \\
\hline 180 & 295 & 595 & 635 & 635 & - & 20 & 2340 & 5.3 & 19 & - \\
\hline 180 & 310 & 610 & - & 1240 & - & 20 & 2340 & 5.3 & 18 & - \\
\hline 180 & 330 & 585 & 872 & 373 & - & 20 & 2340 & 5.3 & 23 & - \\
\hline 180 & 355 & 560 & 623 & 623 & - & 20 & 2340 & 5.3 & 24 & - \\
\hline 180 & 372 & 536 & - & 1252 & - & 20 & 2340 & 5.3 & 21 & - \\
\hline 180 & 355 & 560 & 872 & 373 & - & 20 & 2340 & 5.3 & 25 & - \\
\hline 180 & 385 & 550 & 613 & 613 & - & 20 & 2340 & 5.3 & 29 & - \\
\hline 180 & 409 & 525 & - & 1226 & - & 20 & 2340 & 5.3 & 30 & - \\
\hline 180 & 375 & 544 & 869 & 372 & - & 20 & 2340 & 5.3 & 39 & - \\
\hline 180 & 405 & 508 & 624 & 624 & - & 20 & 2340 & 5.3 & 31 & - \\
\hline 180 & 426 & 494 & - & 1241 & - & 20 & 2340 & 5.3 & 34 & - \\
\hline 193 & 350 & 661 & 1061 & 57 & - & 12 & 2010 & 10.9 & 40 & 2.9 \\
\hline 194 & 350 & 515 & 1061 & 170 & - & 12 & 2010 & 10.9 & 38.6 & 2.7 \\
\hline 196 & 350 & 368 & 1061 & 283 & - & 12 & 2010 & 10.9 & 37.6 & 2.6 \\
\hline 199 & 158 & - & 1061 & 566 & - & 12 & 2010 & 10.9 & 38.6 & 2.5 \\
\hline 158 & 350 & 693 & 1111 & 59 & 3.5 & 12 & 2010 & 10.9 & 53.7 & 3.4 \\
\hline 163 & 350 & 536 & 1105 & 177 & 3.5 & 12 & 2010 & 10.9 & 51 & 3.3 \\
\hline 168 & 350 & 381 & 1100 & 294 & 3.5 & 12 & 2010 & 10.9 & 47.8 & 3.1 \\
\hline 178 & 350 & - & 1089 & 582 & 3.5 & 12 & 2010 & 10.9 & 45.1 & 3 \\
\hline 137 & 350 & 713 & 1143 & 61 & 3.5 & 12 & 2010 & 10.9 & 64.6 & 4.2 \\
\hline 139 & 350 & 555 & 1143 & 183 & 3.5 & 12 & 2010 & 10.9 & 65.4 & 4.5 \\
\hline 143 & 350 & 395 & 1138 & 304 & 3.5 & 12 & 2010 & 10.9 & 63.2 & 3.7 \\
\hline 150 & 350 & - & 1132 & 605 & 3.5 & 12 & 2010 & 10.9 & 63 & 3.4 \\
\hline 180 & 281 & 802 & - & 970 & - & 10 & 2360 & 4.7 & 38.6 & 3.5 \\
\hline 170 & 293 & 648 & - & 919 & - & 10 & 2280 & 6.2 & 38.1 & 3.1 \\
\hline 165 & 337 & 841 & - & 879 & - & 10 & 2220 & 7.8 & 39.3 & 3.3 \\
\hline 190 & 463 & 621 & - & 970 & - & 10 & 2360 & 4.7 & 60.1 & 3.8 \\
\hline 190 & 500 & 621 & - & 919 & 3.24 & 10 & 2280 & 6.2 & 60.2 & 3.7 \\
\hline 180 & 600 & 567 & - & 879 & 5.04 & 10 & 2220 & 7.8 & 62.8 & 3.7 \\
\hline 220 & 537 & 693 & 782 & 138 & - & 20 & 2330 & 4.4 & 50.8 & - \\
\hline 220 & 537 & 693 & 644 & 276 & - & 20 & 2330 & 4.4 & 44.9 & - \\
\hline 220 & 537 & 693 & 506 & 414 & - & 20 & 2330 & 4.4 & 44.6 & - \\
\hline 220 & 537 & 693 & 368 & 552 & - & 20 & 2330 & 4.4 & 42.4 & - \\
\hline 220 & 537 & 693 & 782 & 138 & - & 20 & 2370 & 4 & 54 & - \\
\hline 220 & 537 & 693 & 644 & 276 & - & 20 & 2370 & 4 & 56 & - \\
\hline 220 & 537 & 693 & 506 & 414 & - & 20 & 2370 & 4 & 54.4 & - \\
\hline
\end{tabular}




\begin{tabular}{|c|c|c|c|c|c|c|c|c|c|c|}
\hline $\begin{array}{c}\text { Water } \\
\left(\mathrm{kg} / \mathrm{m}^{3}\right)\end{array}$ & $\begin{array}{l}\text { Cement } \\
\left(\mathrm{kg} / \mathrm{m}^{3}\right)\end{array}$ & $\begin{array}{c}\text { Sand } \\
\left(\mathrm{kg} / \mathrm{m}^{3}\right)\end{array}$ & $\begin{array}{c}\text { NCA } \\
\left(\mathrm{kg} / \mathrm{m}^{3}\right)\end{array}$ & $\begin{array}{c}\text { RCA } \\
\left(\mathrm{kg} / \mathrm{m}^{3}\right)\end{array}$ & $\begin{array}{c}\mathrm{SP} \\
\left(\mathrm{kg} / \mathrm{m}^{3}\right)\end{array}$ & $\begin{array}{c}\text { RCA } \\
\text { Size } \\
\left(\mathrm{kg} / \mathrm{m}^{3}\right)\end{array}$ & $\begin{array}{l}\text { Density } \\
\left(\mathrm{kg} / \mathrm{m}^{3}\right)\end{array}$ & $\begin{array}{c}\text { Absorption } \\
(\%)\end{array}$ & $\begin{array}{c}\mathrm{CS} \\
(\mathrm{MPa})\end{array}$ & $\begin{array}{c}\text { STS } \\
\text { (MPa) }\end{array}$ \\
\hline 220 & 537 & 693 & 368 & 552 & - & 20 & 2370 & 4 & 40.6 & - \\
\hline 220 & 537 & 693 & 782 & 138 & - & 20 & 2390 & 3.6 & 55.2 & - \\
\hline 220 & 537 & 693 & 644 & 276 & - & 20 & 2390 & 3.6 & 53.5 & - \\
\hline 220 & 537 & 693 & 506 & 414 & - & 20 & 2390 & 3.6 & 56.9 & - \\
\hline 220 & 537 & 693 & 368 & 552 & - & 20 & 2390 & 3.6 & 54.7 & - \\
\hline 220 & 537 & 693 & 782 & 138 & - & 20 & 2320 & 4.6 & 50.5 & - \\
\hline 220 & 537 & 693 & 644 & 276 & - & 20 & 2320 & 4.6 & 48.9 & - \\
\hline 220 & 537 & 693 & 506 & 414 & - & 20 & 2320 & 4.6 & 45.8 & - \\
\hline 220 & 537 & 693 & 368 & 552 & - & 20 & 2320 & 4.6 & 40 & - \\
\hline 220 & 537 & 693 & 782 & 138 & - & 20 & 2390 & 3.7 & 54.4 & - \\
\hline 220 & 537 & 693 & 644 & 276 & - & 20 & 2390 & 3.7 & 50.2 & - \\
\hline 220 & 537 & 693 & 506 & 414 & - & 20 & 2390 & 3.7 & 49.5 & - \\
\hline 220 & 537 & 693 & 368 & 552 & - & 20 & 2390 & 3.7 & 40.4 & - \\
\hline 220 & 537 & 693 & 782 & 138 & - & 20 & 2390 & 3.5 & 45 & - \\
\hline 220 & 537 & 693 & 644 & 276 & - & 20 & 2390 & 3.5 & 46.9 & - \\
\hline 220 & 537 & 693 & 506 & 414 & - & 20 & 2390 & 3.5 & 51.4 & - \\
\hline 220 & 537 & 693 & 368 & 552 & - & 20 & 2390 & 3.5 & 53.2 & - \\
\hline 220 & 537 & 693 & 782 & 138 & - & 20 & 2380 & 3.8 & 55.3 & - \\
\hline 220 & 537 & 693 & 644 & 276 & - & 20 & 2380 & 3.8 & 55.9 & - \\
\hline 220 & 537 & 693 & 506 & 414 & - & 20 & 2380 & 3.8 & 52.6 & - \\
\hline 220 & 537 & 693 & 368 & 552 & - & 20 & 2380 & 3.8 & 48 & - \\
\hline 220 & 537 & 693 & 782 & 138 & - & 20 & 2380 & 3.8 & 49.1 & - \\
\hline 220 & 537 & 693 & 644 & 276 & - & 20 & 2380 & 3.8 & 49.9 & - \\
\hline 220 & 537 & 693 & 506 & 414 & - & 20 & 2380 & 3.8 & 50.3 & - \\
\hline 220 & 537 & 693 & 368 & 552 & - & 20 & 2380 & 3.8 & 47.5 & - \\
\hline 220 & 537 & 693 & 782 & 138 & - & 20 & 2400 & 3.5 & 43.2 & - \\
\hline 220 & 537 & 693 & 644 & 276 & - & 20 & 2400 & 3.5 & 53.7 & - \\
\hline 220 & 537 & 693 & 506 & 414 & - & 20 & 2400 & 3.5 & 50 & - \\
\hline 220 & 537 & 693 & 368 & 552 & - & 20 & 2400 & 3.5 & 43.3 & - \\
\hline 220 & 537 & 693 & 782 & 138 & - & 20 & 2370 & 4 & 52.9 & - \\
\hline 220 & 537 & 693 & 644 & 276 & - & 20 & 2370 & 4 & 49.9 & - \\
\hline 220 & 537 & 693 & 506 & 414 & - & 20 & 2370 & 4 & 53.7 & - \\
\hline 220 & 537 & 693 & 368 & 552 & - & 20 & 2370 & 4 & 46 & - \\
\hline 206 & 413 & 606 & - & 987 & - & 25 & 2452 & 4.1 & 51 & - \\
\hline 206 & 413 & 606 & - & 987 & - & 25 & 2452 & 4.1 & 49 & - \\
\hline 206 & 413 & 606 & - & 987 & - & 25 & 2452 & 4.1 & 48 & - \\
\hline 206 & 413 & 606 & 537 & 494 & - & 25 & 2452 & 4.1 & 51 & - \\
\hline 206 & 413 & 606 & 537 & 494 & - & 25 & 2452 & 4.1 & 51 & - \\
\hline 206 & 413 & 606 & 537 & 494 & - & 25 & 2452 & 4.1 & 51 & - \\
\hline 206 & 413 & 606 & 805 & 245 & - & 25 & 2452 & 4.1 & 52 & - \\
\hline 206 & 413 & 606 & 805 & 245 & - & 25 & 2452 & 4.1 & 50 & - \\
\hline 206 & 413 & 606 & 805 & 245 & - & 25 & 2452 & 4.1 & 49 & - \\
\hline 145.6 & 520 & 577.2 & - & 1040 & - & 25 & 2260 & 7.5 & 38.3 & - \\
\hline 145.6 & 520 & 577.2 & - & 1040 & - & 25 & 2260 & 7.5 & 32.9 & - \\
\hline 119.6 & 520 & 577.2 & - & 1040 & - & 25 & 2260 & 7.5 & 33.2 & - \\
\hline 146.2 & 430 & 653.6 & - & 1032 & - & 25 & 2260 & 7.5 & 31.3 & - \\
\hline 146.2 & 430 & 653.6 & - & 1032 & - & 25 & 2260 & 7.5 & 28.4 & - \\
\hline 120.4 & 430 & 653.6 & - & 1032 & - & 25 & 2260 & 7.5 & 28 & - \\
\hline 145.77 & 339 & 728.85 & - & 1050.9 & - & 25 & 2260 & 7.5 & 26.5 & - \\
\hline 145.77 & 339 & 728.85 & - & 1050.9 & - & 25 & 2260 & 7.5 & 23.3 & - \\
\hline 118.65 & 339 & 728.85 & - & 1050.9 & - & 25 & 2260 & 7.5 & 21.6 & - \\
\hline 144.06 & 294 & 767.34 & - & 1029 & - & 25 & 2260 & 7.5 & 21.6 & - \\
\hline 144.06 & 294 & 767.34 & - & 1029 & - & 25 & 2260 & 7.5 & 18 & - \\
\hline 117.6 & 294 & 767.34 & - & 1029 & - & 25 & 2260 & 7.5 & 18.8 & - \\
\hline 146.91 & 249 & 804.27 & - & 1045.8 & - & 25 & 2260 & 7.5 & 16.1 & - \\
\hline 146.91 & 249 & 804.27 & - & 1045.8 & - & 25 & 2260 & 7.5 & 13.4 & - \\
\hline 119.52 & 249 & 804.27 & - & 1045.8 & - & 25 & 2260 & 7.5 & 13.9 & - \\
\hline 179 & 275 & 878 & 735 & 184 & - & 20 & 2320 & 5.3 & 41 & 2.8 \\
\hline
\end{tabular}




\begin{tabular}{|c|c|c|c|c|c|c|c|c|c|c|}
\hline $\begin{array}{c}\text { Water } \\
\left(\mathrm{kg} / \mathrm{m}^{3}\right)\end{array}$ & $\begin{array}{l}\text { Cement } \\
\left(\mathrm{kg} / \mathrm{m}^{3}\right)\end{array}$ & $\begin{array}{c}\text { Sand } \\
\left(\mathrm{kg} / \mathrm{m}^{3}\right)\end{array}$ & $\begin{array}{c}\text { NCA } \\
\left(\mathrm{kg} / \mathrm{m}^{3}\right)\end{array}$ & $\begin{array}{c}\text { RCA } \\
\left(\mathrm{kg} / \mathrm{m}^{3}\right)\end{array}$ & $\begin{array}{c}\mathrm{SP} \\
\left(\mathrm{kg} / \mathrm{m}^{3}\right)\end{array}$ & $\begin{array}{c}\text { RCA } \\
\text { Size } \\
\left(\mathrm{kg} / \mathrm{m}^{3}\right)\end{array}$ & $\begin{array}{l}\text { Density } \\
\left(\mathrm{kg} / \mathrm{m}^{3}\right)\end{array}$ & $\begin{array}{c}\text { Absorption } \\
\text { (\%) }\end{array}$ & $\begin{array}{c}\mathrm{CS} \\
(\mathrm{MPa})\end{array}$ & $\begin{array}{l}\text { STS } \\
\text { (MPa) }\end{array}$ \\
\hline 179 & 275 & 849 & 455 & 455 & - & 20 & 2320 & 5.3 & 44 & 3.1 \\
\hline 179 & 275 & 868 & - & 830 & - & 20 & 2320 & 5.3 & 45 & 2.4 \\
\hline 190 & 380 & 744 & 757 & 189 & - & 20 & 2320 & 5.3 & 50.5 & 3.5 \\
\hline 190 & 380 & 710 & 471 & 471 & - & 20 & 2320 & 5.3 & 45 & 2.7 \\
\hline 190 & 380 & 715 & - & 874 & - & 20 & 2320 & 5.3 & 56 & 3.7 \\
\hline 179 & 275 & 961 & 740 & 185 & - & 20 & 2320 & 5.3 & 33.5 & 2.5 \\
\hline 179 & 275 & 978 & 408 & 408 & - & 20 & 2320 & 5.3 & 32 & 2.5 \\
\hline 179 & 275 & 1010 & - & 640 & - & 20 & 2320 & 5.3 & 32 & 2.3 \\
\hline 190 & 380 & 813 & 767 & 192 & - & 20 & 2320 & 5.3 & 44 & 2.8 \\
\hline 190 & 380 & 822 & 426 & 427 & - & 20 & 2320 & 5.3 & 41 & 2.6 \\
\hline 190 & 380 & 836 & - & 683 & - & 20 & 2320 & 5.3 & 41.5 & 2.3 \\
\hline 179 & 325 & 799 & 839 & 210 & - & 20 & 2320 & 5.3 & 44 & 2.8 \\
\hline 179 & 325 & 831 & 490 & 490 & - & 20 & 2320 & 5.3 & 41 & 2.7 \\
\hline 179 & 325 & 825 & - & 923 & - & 20 & 2320 & 5.3 & 33.5 & 2.3 \\
\hline 173 & 385 & 698 & 892 & 223 & - & 20 & 2320 & 5.3 & 53.5 & 3.1 \\
\hline 173 & 385 & 742 & 515 & 515 & - & 20 & 2320 & 5.3 & 54 & 3.9 \\
\hline 173 & 385 & 746 & - & 963 & - & 20 & 2320 & 5.3 & 40 & 2.4 \\
\hline 159.6 & 380 & 862.4 & 489.3 & 489.3 & 5.7 & 20 & 2330 & 6.1 & 41.6 & - \\
\hline 193.8 & 380 & 934.1 & - & 867.7 & 6.46 & 20 & 2330 & 6.1 & 31.4 & - \\
\hline 197.6 & 380 & 862.4 & 489.3 & 489.3 & 5.7 & 20 & 2330 & 6.1 & 35.5 & - \\
\hline 231.8 & 380 & 934.1 & - & 867.7 & 6.46 & 20 & 2330 & 6.1 & 26 & - \\
\hline 167.2 & 380 & 862.4 & 489.3 & 489.3 & 5.7 & 20 & 2320 & 5.8 & 44.6 & - \\
\hline 193.8 & 380 & 934.1 & - & 867.7 & 6.46 & 20 & 2320 & 5.8 & 36.7 & - \\
\hline 235.6 & 380 & 934.1 & - & 867.7 & 6.46 & 20 & 2320 & 5.8 & 29.5 & - \\
\hline 155.8 & 380 & 818.5 & 840.9 & 210.2 & 4.56 & 20 & 2360 & 3.9 & 46.1 & - \\
\hline 159.6 & 380 & 862.4 & 489.3 & 489.3 & 5.7 & 20 & 2360 & 3.9 & 45.1 & - \\
\hline 171 & 380 & 934.1 & - & 867.7 & 6.46 & 20 & 2360 & 3.9 & 42.9 & - \\
\hline 190 & 380 & 818.5 & 840.9 & 210.2 & 4.56 & 20 & 2360 & 3.9 & 39.3 & - \\
\hline 197.6 & 380 & 862.4 & 489.3 & 489.3 & 5.7 & 20 & 2360 & 3.9 & 39.5 & - \\
\hline 205.2 & 380 & 934.1 & - & 867.7 & 6.46 & 20 & 2360 & 3.9 & 37.7 & - \\
\hline 159.6 & 380 & 818.5 & 840.9 & 210.2 & 4.56 & 20 & 2350 & 4.5 & 48.1 & - \\
\hline 163.4 & 380 & 862.4 & 489.3 & 489.3 & 5.7 & 20 & 2350 & 4.5 & 41 & - \\
\hline 152 & 380 & 934.1 & - & 867.7 & 6.46 & 20 & 2350 & 4.5 & 38.7 & - \\
\hline 193.8 & 380 & 818.5 & 840.9 & 210.2 & 4.56 & 20 & 2350 & 4.5 & 42.7 & - \\
\hline 197.6 & 380 & 862.4 & 489.3 & 489.3 & 5.7 & 20 & 2350 & 4.5 & 35.4 & - \\
\hline 190 & 380 & 934.1 & - & 867.7 & 6.46 & 20 & 2350 & 4.5 & 31.4 & - \\
\hline 159.6 & 380 & 818.5 & 840.9 & 210.2 & 4.56 & 20 & 2350 & 4.7 & 48.5 & - \\
\hline 159.6 & 380 & 862.4 & 489.3 & 489.3 & 5.7 & 20 & 2350 & 4.7 & 45.4 & - \\
\hline 163.4 & 380 & 934.1 & - & 867.7 & 6.46 & 20 & 2350 & 4.7 & 37 & - \\
\hline 197.6 & 380 & 818.5 & 840.9 & 210.2 & 4.56 & 20 & 2350 & 4.7 & 41.3 & $0-$ \\
\hline 197.6 & 380 & 862.4 & 489.3 & 489.3 & 5.7 & 20 & 2350 & 4.7 & 36.8 & - \\
\hline 212.8 & 380 & 934.1 & - & 867.7 & 6.46 & 20 & 2350 & 4.7 & 31.2 & - \\
\hline 159.8 & 340 & 556 & 1020 & 238 & - & 20 & 2336 & 3.6 & 50 & - \\
\hline 159.8 & 340 & 556 & 638 & 596 & - & 20 & 2315 & 3.6 & 45.3 & - \\
\hline 159.8 & 340 & 556 & 319 & 894 & - & 20 & 2295 & 3.6 & 44 & - \\
\hline 137.1 & 380 & 927 & 869.2 & 202 & - & 10 & 2470 & 3.7 & 108 & 5.7 \\
\hline 146.5 & 380 & 927 & 543.2 & 505.1 & - & 10 & 2470 & 3.7 & 104.8 & 5 \\
\hline 162.3 & 380 & 927 & - & 1010.2 & - & 10 & 2470 & 3.7 & 108.5 & 5.1 \\
\hline 138.2 & 380 & 927 & 869.2 & 195 & - & 10 & 2390 & 4.9 & 102.5 & 6.3 \\
\hline 149.8 & 380 & 927 & 543.2 & 487.5 & - & 10 & 2390 & 4.9 & 103.1 & 5.1 \\
\hline 170.4 & 380 & 927 & - & 975.1 & - & 10 & 2390 & 4.9 & 100.8 & 5.9 \\
\hline 139.7 & 380 & 927 & 869.2 & 187.8 & - & 10 & 2300 & 5.9 & 104.3 & 5.3 \\
\hline 153.1 & 380 & 927 & 543.4 & 469.4 & - & 10 & 2300 & 5.9 & 96.8 & 6.2 \\
\hline 175 & 380 & 927 & - & 938.8 & - & 10 & 2300 & 5.9 & 91.2 & 4.2 \\
\hline 185.4 & 309 & 864 & 848 & 211 & 1.0197 & 16 & 2380 & 6.9 & 42.9 & - \\
\hline 191.7 & 320 & 817.5 & 538 & 538 & 1.056 & 16 & 2380 & 6.9 & 42.5 & - \\
\hline
\end{tabular}




\begin{tabular}{|c|c|c|c|c|c|c|c|c|c|c|}
\hline $\begin{array}{c}\text { Water } \\
\left(\mathrm{kg} / \mathrm{m}^{3}\right)\end{array}$ & $\begin{array}{l}\text { Cement } \\
\left(\mathrm{kg} / \mathrm{m}^{3}\right)\end{array}$ & $\begin{array}{c}\text { Sand } \\
\left(\mathrm{kg} / \mathrm{m}^{3}\right)\end{array}$ & $\begin{array}{c}\text { NCA } \\
\left(\mathrm{kg} / \mathrm{m}^{3}\right)\end{array}$ & $\begin{array}{c}\text { RCA } \\
\left(\mathrm{kg} / \mathrm{m}^{3}\right)\end{array}$ & $\begin{array}{c}\mathrm{SP} \\
\left(\mathrm{kg} / \mathrm{m}^{3}\right)\end{array}$ & $\begin{array}{c}\text { RCA } \\
\text { Size } \\
\left(\mathrm{kg} / \mathrm{m}^{3}\right)\end{array}$ & $\begin{array}{l}\text { Density } \\
\left(\mathrm{kg} / \mathrm{m}^{3}\right)\end{array}$ & $\begin{array}{c}\text { Absorption } \\
\text { (\%) }\end{array}$ & $\begin{array}{c}\mathrm{CS} \\
(\mathrm{MPa})\end{array}$ & $\begin{array}{c}\text { STS } \\
\text { (MPa) }\end{array}$ \\
\hline 201.6 & 336 & 785 & - & 1060 & 1.1088 & 16 & 2380 & 6.9 & 40.9 & - \\
\hline 192.5 & 386 & 829 & 808 & 202 & 2.0458 & 16 & 2380 & 6.9 & 51.6 & - \\
\hline 200 & 399 & 795 & 504 & 504 & 2.1147 & 16 & 2380 & 6.9 & 51.6 & - \\
\hline 210 & 420 & 738 & - & 1014 & 2.226 & 16 & 2380 & 6.9 & 50.3 & - \\
\hline 205 & 300 & 697 & - & 1075 & - & 20 & 2450 & 3.1 & 35 & 2.5 \\
\hline 205 & 300 & 697 & - & 1027 & - & 20 & 2370 & 7.1 & 29.2 & 2.4 \\
\hline 205 & 300 & 697 & - & 1027 & - & 20 & 2360 & 7.8 & 27.7 & 1.9 \\
\hline 180 & 350 & 706 & - & 1089 & - & 20 & 2450 & 3.1 & 47.6 & 3.4 \\
\hline 180 & 350 & 706 & - & 1041 & - & 20 & 2370 & 7.1 & 42 & 2.6 \\
\hline 180 & 350 & 706 & - & 1041 & - & 20 & 2360 & 7.8 & 42.9 & 2.6 \\
\hline 185 & 425 & 696 & - & 1028 & - & 20 & 2450 & 3.1 & 60 & 3.9 \\
\hline 185 & 425 & 696 & - & 982 & - & 20 & 2370 & 7.1 & 53.7 & 3.7 \\
\hline 185 & 425 & 696 & - & 982 & - & 20 & 2360 & 7.8 & 53.2 & 3.4 \\
\hline 165 & 485 & 685 & - & 1039 & - & 20 & 2450 & 3.1 & 78.2 & 4.7 \\
\hline 165 & 485 & 685 & - & 979 & - & 20 & 2370 & 7.1 & 71.2 & 4.1 \\
\hline 165 & 485 & 685 & - & 982 & - & 20 & 2360 & 7.8 & 65.4 & 4.2 \\
\hline 178.3 & 358 & 730.4 & 783.6 & 299.3 & 0.3 & 19 & 2570 & 2.7 & 33.6 & 3.9 \\
\hline 178.3 & 358 & 730.4 & 458.3 & 598.4 & 0.3 & 19 & 2570 & 2.7 & 30.4 & 3.9 \\
\hline 178.3 & 358 & 730.4 & - & 1020 & 0.3 & 19 & 2570 & 2.7 & 29.1 & 3.3 \\
\hline 195 & 300 & 787.1 & 756.4 & 189.1 & - & 20 & 2300 & 5.2 & 39.5 & - \\
\hline 195 & 300 & 737.4 & 485.5 & 485.5 & - & 20 & 2300 & 5.2 & 40.8 & - \\
\hline 195 & 300 & 712.6 & - & 951.4 & - & 20 & 2300 & 5.2 & 43.7 & - \\
\hline 195 & 300 & 814.4 & 733 & 183.2 & - & 20 & 2300 & 5.5 & 41 & - \\
\hline 195 & 300 & 804.2 & 450.7 & 450.7 & - & 20 & 2300 & 5.5 & 38.8 & - \\
\hline 195 & 300 & 807.9 & - & 855.2 & - & 20 & 2300 & 5.5 & 39.9 & - \\
\hline 214.2 & 210 & 929 & - & 966 & - & 22 & 2451 & 7.8 & 19.7 & 2 \\
\hline 196 & 280 & 866 & - & 940 & - & 22 & 2387 & 6.9 & 35.7 & 2.9 \\
\hline 161 & 350 & 858 & - & 974 & 3.5 & 22 & 2362 & 4.2 & 66.8 & 4.6 \\
\hline 212.1 & 210 & 932 & - & 970 & - & 22 & 2456 & 7.5 & 21.8 & 2 \\
\hline 193.2 & 280 & 870 & - & 970 & - & 22 & 2455 & 6.4 & 36.1 & 2.9 \\
\hline 157.5 & 350 & 858 & - & 1029 & 3.5 & 22 & 2496 & 4.2 & 68.5 & 4.8 \\
\hline 207.9 & 210 & 938 & - & 953 & - & 22 & 2401 & 7.6 & 21 & 2.1 \\
\hline 187.6 & 280 & 877 & - & 988 & - & 22 & 2484 & 5.4 & 41.1 & 3 \\
\hline 150.5 & 350 & 868 & - & 982 & 3.5 & 22 & 2363 & 3.6 & 70.2 & 4.9 \\
\hline 205.8 & 210 & 943 & - & 977 & - & 22 & 2447 & 6.9 & 23.6 & 2.2 \\
\hline 190.4 & 280 & 873 & - & 962 & - & 22 & 2458 & 5.8 & 39.7 & 3 \\
\hline 157.5 & 350 & 858 & - & 1016 & 3.5 & 22 & 2464 & 3.9 & 66.5 & 5 \\
\hline 179 & 275 & 878 & 735 & 184 & - & 19 & 2320 & 5.3 & 49.3 & 4.1 \\
\hline 179 & 275 & 849 & 455 & 455 & - & 19 & 2320 & 5.3 & 47.5 & 4.7 \\
\hline 179 & 275 & 868 & - & 830 & - & 19 & 2320 & 5.3 & 53.7 & 4.9 \\
\hline 190 & 380 & 714 & 757 & 189 & - & 19 & 2320 & 5.3 & 64.8 & 4.7 \\
\hline 190 & 380 & 710 & 471 & 471 & - & 19 & 2320 & 5.3 & 63.5 & 4.8 \\
\hline 190 & 380 & 715 & - & 874 & - & 19 & 2320 & 5.3 & 65.1 & 5 \\
\hline 179 & 275 & 961 & 740 & 185 & - & 19 & 2320 & 5.3 & 64.8 & 2.5 \\
\hline 179 & 275 & 978 & 408 & 408 & - & 19 & 2320 & 5.3 & 63.5 & 2.4 \\
\hline 179 & 275 & 1010 & - & 640 & - & 19 & 2320 & 5.3 & 65.1 & 2.3 \\
\hline 190 & 380 & 813 & 767 & 192 & - & 19 & 2320 & 5.3 & 54.9 & 3.2 \\
\hline 190 & 380 & 822 & 426 & 427 & - & 19 & 2320 & 5.3 & 51.5 & 2.7 \\
\hline 190 & 380 & 836 & - & 683 & - & 19 & 2320 & 5.3 & 50.3 & 2.4 \\
\hline 179 & 325 & 799 & 839 & 210 & - & 19 & 2320 & 5.3 & 56.5 & 2.9 \\
\hline 179 & 325 & 831 & 490 & 490 & - & 19 & 2320 & 5.3 & 48.9 & 2.6 \\
\hline 179 & 325 & 825 & - & 923 & - & 19 & 2320 & 5.3 & 43.1 & 2.4 \\
\hline 173 & 385 & 698 & 892 & 233 & - & 19 & 2320 & 5.3 & 67.4 & 3.5 \\
\hline 173 & 385 & 742 & 515 & 515 & - & 19 & 2320 & 5.3 & 61.2 & 2.9 \\
\hline 173 & 385 & 746 & - & 963 & - & 19 & 2320 & 5.3 & 53.7 & 2.5 \\
\hline
\end{tabular}




\section{References}

1. Erdem, S.; Dawson, A.R.; Thom, N.H. Microstructure-linked strength properties and impact response of conventional and recycled concrete reinforced with steel and synthetic macro fibres. Constr. Build. Mater. 2011, 25, 4025-4036. [CrossRef]

2. Marinković, S.; Radonjanin, V.; Malešev, M.; Ignjatović, I. Comparative environmental assessment of natural and recycled aggregate concrete. Waste Manag. 2010, 30, 2255-2264. [CrossRef] [PubMed]

3. Behera, M.; Bhattacharyya, S.; Minocha, A.; Deoliya, R.; Maiti, S. Recycled aggregate from C\&D waste \& its use in concrete-A breakthrough towards sustainability in construction sector: A review. Constr. Build. Mater. 2014, 68, 501-516. [CrossRef]

4. Pacheco-Torgal, F.; Ding, Y.; Miraldo, S.; Abdollahnejad, Z.; Labrincha, J. Are geopolymers more suitable than Portland cement to produce high volume recycled aggregates HPC? Constr. Build. Mater. 2012, 36, 1048-1052. [CrossRef]

5. Marie, I.; Quiasrawi, H. Closed-loop recycling of recycled concrete aggregates. J. Clean. Prod. 2012, 37, 243-248. [CrossRef]

6. Topçu, I.B.; Şengel, S. Properties of concretes produced with waste concrete aggregate. Cem. Concr. Res. 2004, 34, 1307-1312. [CrossRef]

7. Topçu, I. Physical and mechanical properties of concretes produced with waste concrete. Cem. Concr. Res. 1997, 27, 1817-1823. [CrossRef]

8. Çakir, O. Experimental analysis of properties of recycled coarse aggregate (RCA) concrete with mineral additives. Constr. Build. Mater. 2014, 68, 17-25. [CrossRef]

9. Younis, K.; Pilakoutas, K. Strength prediction model and methods for improving recycled aggregate concrete. Constr. Build. Mater. 2013, 49, 688-701. [CrossRef]

10. Flower, D.J.M.; Sanjayan, J.G. Green house gas emissions due to concrete manufacture. Int. J. Life Cycle Assess. 2007, 12, 282-288. [CrossRef]

11. Turner, L.K.; Collins, F. Carbon dioxide equivalent (CO2-e) emissions: A comparison between geopolymer and OPC cement concrete. Constr. Build. Mater. 2013, 43, 125-130. [CrossRef]

12. Thomas, A.; Lombardi, D.R.; Hunt, D.; Gaterell, M. Estimating carbon dioxide emissions for aggregate use. Proc. Inst. Civ. Eng. Eng. Sustain. 2009, 162, 135-144. [CrossRef]

13. Dong, J.; Wang, Q.; Guan, Z. Material properties of basalt fibre reinforced concrete made with recycled earthquake waste. Constr. Build. Mater. 2017, 130, 241-251. [CrossRef]

14. Ahmad, W.; Ahmad, A.; Ostrowski, K.A.; Aslam, F.; Joyklad, P. A scientometric review of waste material utilization in concrete for sustainable construction. Case Stud. Constr. Mater. 2021, 15, e00683. [CrossRef]

15. Sufian, M.; Ullah, S.; Ostrowski, K.; Ahmad, A.; Zia, A.; Śliwa-Wieczorek, K.; Siddiq, M.; Awan, A. An Experimental and Empirical Study on the Use of Waste Marble Powder in Construction Material. Materials 2021, 14, 3829. [CrossRef]

16. Ahmad, W.; Ahmad, A.; Ostrowski, K.A.; Aslam, F.; Joyklad, P.; Zajdel, P. Sustainable approach of using sugarcane bagasse ash in cement-based composites: A systematic review. Case Stud. Constr. Mater. 2021, 15, e00698. [CrossRef]

17. Duan, Z.; Singh, A.; Xiao, J.; Hou, S. Combined use of recycled powder and recycled coarse aggregate derived from construction and demolition waste in self-compacting concrete. Constr. Build. Mater. 2020, 254, 119323. [CrossRef]

18. Li, X.; Qin, D.; Hu, Y.; Ahmad, W.; Ahmad, A.; Aslam, F.; Joyklad, P. A systematic review of waste materials in cement-based composites for construction applications. J. Build. Eng. 2021, 45, 103447. [CrossRef]

19. Bairagi, N.; Vidyadhara, H.; Ravande, K. Mix design procedure for recycled aggregate concrete. Constr. Build. Mater. 1990, 4 , 188-193. [CrossRef]

20. Feng, D.-C.; Liu, Z.-T.; Wang, X.-D.; Chen, Y.; Chang, J.-Q.; Wei, D.-F.; Jiang, Z.-M. Machine learning-based compressive strength prediction for concrete: An adaptive boosting approach. Constr. Build. Mater. 2020, 230, 117000. [CrossRef]

21. Van Dao, D.; Adeli, H.; Ly, H.-B.; Le, L.M.; Le, V.M.; Le, T.-T.; Pham, B.T. A Sensitivity and Robustness Analysis of GPR and ANN for High-Performance Concrete Compressive Strength Prediction Using a Monte Carlo Simulation. Sustainability 2020, 12, 830. [CrossRef]

22. Javed, M.F.; Amin, M.N.; Shah, M.I.; Khan, K.; Iftikhar, B.; Farooq, F.; Aslam, F.; Alyousef, R.; Alabduljabbar, H. Applications of Gene Expression Programming and Regression Techniques for Estimating Compressive Strength of Bagasse Ash based Concrete. Crystals 2020, 10, 737. [CrossRef]

23. Gholampour, A.; Gandomi, A.; Ozbakkaloglu, T. New formulations for mechanical properties of recycled aggregate concrete using gene expression programming. Constr. Build. Mater. 2017, 130, 122-145. [CrossRef]

24. Han, T.; Siddique, A.; Khayat, K.; Huang, J.; Kumar, A. An ensemble machine learning approach for prediction and optimization of modulus of elasticity of recycled aggregate concrete. Constr. Build. Mater. 2020, 244, 118271. [CrossRef]

25. Ahmad, A.; Chaiyasarn, K.; Farooq, F.; Ahmad, W.; Suparp, S.; Aslam, F. Compressive Strength Prediction via Gene Expression Programming (GEP) and Artificial Neural Network (ANN) for Concrete Containing RCA. Buildings 2021, 11, 324. [CrossRef]

26. Ahmad, A.; Ahmad, W.; Chaiyasarn, K.; Ostrowski, K.A.; Aslam, F.; Zajdel, P.; Joyklad, P. Prediction of Geopolymer Concrete Compressive Strength Using Novel Machine Learning Algorithms. Polymers 2021, 13, 3389. [CrossRef]

27. Huang, J.; Sun, Y.; Zhang, J. Reduction of computational error by optimizing SVR kernel coefficients to simulate concrete compressive strength through the use of a human learning optimization algorithm. Eng. Comput. 2021, 1, 3. [CrossRef]

28. Sarir, P.; Chen, J.; Asteris, P.G.; Armaghani, D.J.; Tahir, M.M. Developing GEP tree-based, neuro-swarm, and whale optimization models for evaluation of bearing capacity of concrete-filled steel tube columns. Eng. Comput. 2021, 37, 1-19. [CrossRef] 
29. Balf, F.R.; Kordkheili, H.M. A New Method for Predicting the Ingredients of Self-Compacting Concrete (SCC) Including Fly Ash (FA) Using Data Envelopment Analysis (DEA). Arab. J. Sci. Eng. 2021, 46, 4439-4460. [CrossRef]

30. Ahmad, A.; Farooq, F.; Ostrowski, K.; Śliwa-Wieczorek, K.; Czarnecki, S. Application of Novel Machine Learning Techniques for Predicting the Surface Chloride Concentration in Concrete Containing Waste Material. Materials 2021, 14, 2297. [CrossRef]

31. Azimi-Pour, M.; Eskandari-Naddaf, H.; Pakzad, A. Linear and non-linear SVM prediction for fresh properties and compressive strength of high volume fly ash self-compacting concrete. Constr. Build. Mater. 2020, 230, 117021. [CrossRef]

32. Saha, P.; Debnath, P.; Thomas, P. Prediction of fresh and hardened properties of self-compacting concrete using support vector regression approach. Neural Comput. Appl. 2020, 32, 7995-8010. [CrossRef]

33. Shahmansouri, A.A.; Bengar, H.A.; Jahani, E. Predicting compressive strength and electrical resistivity of eco-friendly concrete containing natural zeolite via GEP algorithm. Constr. Build. Mater. 2019, 229, 116883. [CrossRef]

34. Aslam, F.; Farooq, F.; Amin, M.N.; Khan, K.; Waheed, A.; Akbar, A.; Javed, M.F.; Alyousef, R.; Alabdulijabbar, H. Applications of Gene Expression Programming for Estimating Compressive Strength of High-Strength Concrete. Adv. Civ. Eng. 2020, 2020, 8850535. [CrossRef]

35. Farooq, F.; Amin, M.N.; Khan, K.; Sadiq, M.R.; Javed, M.F.F.; Aslam, F.; Alyousef, R. A Comparative Study of Random Forest and Genetic Engineering Programming for the Prediction of Compressive Strength of High Strength Concrete (HSC). Appl. Sci. 2020, 10, 7330. [CrossRef]

36. Asteris, P.G.; Kolovos, K. Self-compacting concrete strength prediction using surrogate models. Neural Comput. Appl. 2019, 31, 409-424. [CrossRef]

37. Selvaraj, S.; Sivaraman, S. Prediction model for optimized self-compacting concrete with fly ash using response surface method based on fuzzy classification. Neural Comput. Appl. 2019, 31, 1365-1373. [CrossRef]

38. Zhang, J.; Ma, G.; Huang, Y.; Sun, J.; Aslani, F.; Nener, B. Modelling uniaxial compressive strength of lightweight self-compacting concrete using random forest regression. Constr. Build. Mater. 2019, 210, 713-719. [CrossRef]

39. Kaveh, A.; Bakhshpoori, T.; Hamze-Ziabari, S.M. M5' and Mars Based Prediction Models for Properties of Self-compacting Concrete Containing Fly Ash. Period. Polytech. Civ. Eng. 2018, 62, 281-294. [CrossRef]

40. Sathyan, D.; Anand, K.B.; Prakash, A.J.; Premjith, B. Modeling the Fresh and Hardened Stage Properties of Self-Compacting Concrete using Random Kitchen Sink Algorithm. Int. J. Concr. Struct. Mater. 2018, 12, 24. [CrossRef]

41. Vakhshouri, B.; Nejadi, S. Prediction of compressive strength of self-compacting concrete by ANFIS models. Neurocomputing 2018, 280, 13-22. [CrossRef]

42. Douma, O.B.; Boukhatem, B.; Ghrici, M.; Tagnit-Hamou, A. Prediction of properties of self-compacting concrete containing fly ash using artificial neural network. Neural Comput. Appl. 2017, 28,707-718. [CrossRef]

43. Abu Yaman, M.; Elaty, M.A.; Taman, M. Predicting the ingredients of self compacting concrete using artificial neural network. Alexandria Eng. J. 2017, 56, 523-532. [CrossRef]

44. Ahmad, A.; Farooq, F.; Niewiadomski, P.; Ostrowski, K.; Akbar, A.; Aslam, F.; Alyousef, R. Prediction of Compressive Strength of Fly Ash Based Concrete Using Individual and Ensemble Algorithm. Materials 2021, 14, 794. [CrossRef]

45. Farooq, F.; Ahmed, W.; Akbar, A.; Aslam, F.; Alyousef, R. Predictive modeling for sustainable high-performance concrete from industrial wastes: A comparison and optimization of models using ensemble learners. J. Clean. Prod. 2021, 292, 126032. [CrossRef]

46. Bušić, R.; Benšić, M.; Miličević, I.; Strukar, K. Prediction Models for the Mechanical Properties of Self-Compacting Concrete with Recycled Rubber and Silica Fume. Materials 2020, 13, 1821. [CrossRef] [PubMed]

47. Javed, M.F.; Farooq, F.; Memon, S.A.; Akbar, A.; Khan, M.A.; Aslam, F.; Alyousef, R.; Alabduljabbar, H.; Rehman, S.K.U. New Prediction Model for the Ultimate Axial Capacity of Concrete-Filled Steel Tubes: An Evolutionary Approach. Crystals 2020, 10, 741. [CrossRef]

48. Al-Mughanam, T.; Aldhyani, T.; AlSubari, B.; Al-Yaari, M. Modeling of Compressive Strength of Sustainable Self-Compacting Concrete Incorporating Treated Palm Oil Fuel Ash Using Artificial Neural Network. Sustainability 2020, 12, 9322. [CrossRef]

49. Nematzadeh, M.; Shahmansouri, A.A.; Fakoor, M. Post-fire compressive strength of recycled PET aggregate concrete reinforced with steel fibers: Optimization and prediction via RSM and GEP. Constr. Build. Mater. 2020, 252, 119057. [CrossRef]

50. Song, H.; Ahmad, A.; Ostrowski, K.A.; Dudek, M. Analyzing the Compressive Strength of Ceramic Waste-Based Concrete Using Experiment and Artificial Neural Network (ANN) Approach. Materials 2021, 14, 4518. [CrossRef]

51. Ahmad, A.; Ostrowski, K.; Maślak, M.; Farooq, F.; Mehmood, I.; Nafees, A. Comparative Study of Supervised Machine Learning Algorithms for Predicting the Compressive Strength of Concrete at High Temperature. Materials 2021, 14, 4222. [CrossRef] [PubMed]

52. Song, H.; Ahmad, A.; Farooq, F.; Ostrowski, K.A.; Maślak, M.; Czarnecki, S.; Aslam, F. Predicting the compressive strength of concrete with fly ash admixture using machine learning algorithms. Constr. Build. Mater. 2021, 308, 125021. [CrossRef]

53. Ahmad, W.; Ahmad, A.; Ostrowski, K.A.; Aslam, F.; Joyklad, P.; Zajdel, P. Application of Advanced Machine Learning Approaches to Predict the Compressive Strength of Concrete Containing Supplementary Cementitious Materials. Materials 2021, $14,5762$. [CrossRef] [PubMed]

54. Feng, D.-C.; Li, J. Stochastic Nonlinear Behavior of Reinforced Concrete Frames. II: Numerical Simulation. J. Struct. Eng. 2016, 142, 04015163. [CrossRef]

55. Feng, D.-C.; Liu, Z.-T.; Wang, X.-D.; Jiang, Z.-M.; Liang, S.-X. Failure mode classification and bearing capacity prediction for reinforced concrete columns based on ensemble machine learning algorithm. Adv. Eng. Inform. 2020, 45, 101126. [CrossRef] 
56. Ahmad, A.; Ahmad, W.; Aslam, F.; Joyklad, P. Compressive strength prediction of fly ash-based geopolymer concrete via advanced machine learning techniques. Case Stud. Constr. Mater. 2021, 16, e00840. [CrossRef]

57. Zhang, J.; Huang, Y.; Aslani, F.; Ma, G.; Nener, B. A hybrid intelligent system for designing optimal proportions of recycled aggregate concrete. J. Clean. Prod. 2020, 273, 122922. [CrossRef] 